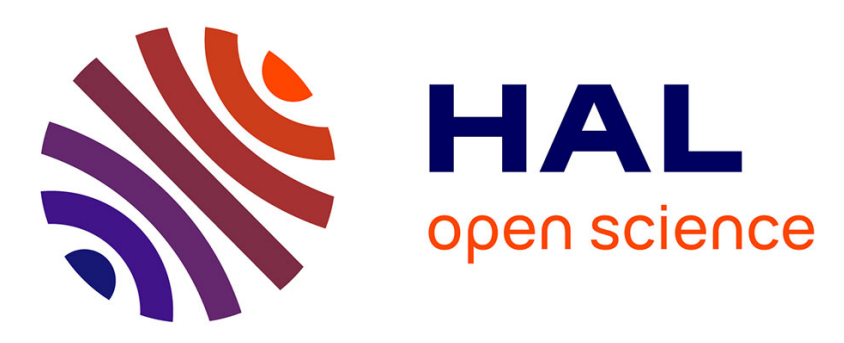

\title{
A swarm of small shield volcanoes on Syria Planum, Mars
}

Ana Rita Baptista, Nicolas Mangold, Véronique Ansan, David Baratoux, Philippe Lognonné, Eduardo I. Alves, David A. Williams, Jacob E. Bleacher, Philippe Masson, Gerhard Neukum

\section{To cite this version:}

Ana Rita Baptista, Nicolas Mangold, Véronique Ansan, David Baratoux, Philippe Lognonné, et al.. A swarm of small shield volcanoes on Syria Planum, Mars. Journal of Geophysical Research. Planets, 2008, 113 (E9), pp.E09010. 10.1029/2007JE002945 . hal-00365570

\section{HAL Id: hal-00365570 https://hal.science/hal-00365570}

Submitted on 23 Dec 2019

HAL is a multi-disciplinary open access archive for the deposit and dissemination of scientific research documents, whether they are published or not. The documents may come from teaching and research institutions in France or abroad, or from public or private research centers.
L'archive ouverte pluridisciplinaire HAL, est destinée au dépôt et à la diffusion de documents scientifiques de niveau recherche, publiés ou non, émanant des établissements d'enseignement et de recherche français ou étrangers, des laboratoires publics ou privés. 


\title{
A swarm of small shield volcanoes on Syria Planum, Mars
}

\author{
Ana Rita Baptista, ${ }^{1,2}$ Nicolas Mangold, ${ }^{2}$ Véronique Ansan, ${ }^{2}$ David Baratoux, ${ }^{3}$ \\ Philippe Lognonné, ${ }^{1}$ Eduardo I. Alves, ${ }^{4}$ David A. Williams, ${ }^{5}$ Jacob E. Bleacher, ${ }^{6}$ \\ Philippe Masson, ${ }^{2}$ and Gerhard Neukum ${ }^{7}$ \\ Received 25 May 2007; revised 6 May 2008; accepted 21 July 2008; published 26 September 2008.
}

[1] This study focuses on the volcanism in Syria Planum, located at the center of the Tharsis bulge at an altitude of 6 to $8 \mathrm{~km}$ above Mars datum. Syria Planum was previously recognized as a center for the tectonic activity of Tharsis, but not as a major locus for volcanic activity, despite its centrality over the bulge. Using high-resolution images from the high resolution stereo camera on Mars Express combined with Mars Observer Laser Altimeter data, we have characterized a volcanic system that reveals a number of very interesting aspects of Mars volcanism. We identified a swarm of tens of coalesced shallow volcanic edifices, typically $10-30 \mathrm{~km}$ diameter, $0.1-0.2 \mathrm{~km}$ high, and with slopes around $0.5^{\circ}$. These characteristics are similar to those of small shield volcanoes found in Iceland. In addition, an intermediate-sized volcano, which is the source of lava flows that extend over $>200 \mathrm{~km}$, is observed west of this shield swarm. Our study characterizes a previously unrecognized volcanic assemblage on Mars which appears to be much more developed than was documented before, in terms of morphology, inferred origin, and periodicity of eruption. The estimated lava flux of the Syria Planum volcanoes is of the same order as the lava flux of Tharsis Montes. These characteristics suggest that Syria Planum experienced a very specific style of volcanism, which we dated to the Hesperian period.

Citation: Baptista, A. R., N. Mangold, V. Ansan, D. Baratoux, P. Lognonné, E. I. Alves, D. A. Williams, J. E. Bleacher, P. Masson, and G. Neukum (2008), A swarm of small shield volcanoes on Syria Planum, Mars, J. Geophys. Res., 113, E09010, doi:10.1029/2007JE002945.

\section{Introduction}

[2] Mars exhibits a great variety of volcanic landforms. Several types of edifices (Montes, Paterae, etc.), as well as volcanic plains, exist in both the northern and the southern hemispheres of Mars [e.g., Carr, 1975; Mutch et al., 1976; Carr, 1981; Greeley and Spudis, 1981; Mouginis-Mark et al., 1992; Carr, 1996]. The four most prominent shield volcanoes, Ascraeus, Pavonis, Arsia, and Olympus Mons, are located on the Tharsis province. Large volcanic edifices also occur in the Elysium region, $\sim 4500 \mathrm{~km}$ west of Olympus Mons, although with significant contrasts in structure, composition, and eruptive style from those of the Tharsis province. The extensive lava flows associated

\footnotetext{
${ }^{1}$ Géophysique Spatiale et Planétaire, Institut de Physique du Globe de Paris, Saint Maur des Fossés, France.

${ }^{2}$ IDES, Université Paris XI, Orsay, France.

${ }^{3}$ Laboratoire Dynamique Terrestre et Planétaire, UMR5562 Observatoire Midi-Pyrénées, Université de Toulouse III, Toulouse, France.

${ }^{4}$ Centro de Geofísica da Universidade de Coimbra, Coimbra, Portugal.

${ }^{5}$ School of Earth and Space Exploration, Arizona State University, Tempe, Arizona, USA.

${ }^{6}$ Planetary Geodynamics Laboratory, NASA Goddard Space Flight Center, Greenbelt, Maryland, USA.

${ }^{7}$ Institut für Geologische Wissenschaften, Freie Universität Berlin, Berlin, Germany.
}

Copyright 2008 by the American Geophysical Union. 0148-0227/08/2007JE002945 with both the Tharsis and Elysium shields suggest that numerous smaller volcanic landforms of various types should also exist [e.g., Plescia, 1981; Mouginis-Mark et al., 1992; Hodges and Moore, 1994]. Much of the knowledge of the physical volcanology of Mars comes from morphologic analyses of Mariner 9 and Viking Orbiter images [e.g., Carr, 1973, 1974; Mouginis-Mark et al., 1992]. Using new imagery and altimetry data from the recent missions Mars Global Surveyor (MGS) and Mars Odyssey, many smaller volcanic features were detected in other regions, such as Tempe Terra, Cerberus Fossae, and the Tharsis region [e.g., Tanaka and Dohm, 1989; Davis and Tanaka, 1993; Webb et al., 2001; Hauber and Kronberg, 2001; Sakimoto et al., 2003; Sakimoto, 2003; Vaucher et al., 2006; Bleacher et al., 2007; Hauber et al., 2007].

[3] In this study, we show that the high resolution stereo camera (HRSC) images allow us to identify, characterize, and map a suite of volcanic landforms in the Syria Planum region, a plains-style volcanic region where the identification of these landforms was limited in detail with Viking imagery. Syria Planum is a broad plateau located at the summit of the Tharsis rise $(>6 \mathrm{~km}$ high above Mars Observer Laser Altimeter (MOLA) datum). Plescia and Saunders [1982] first recognized Syria Planum as a center of tectonic activity. This magmatic/tectonic driven province has been interpreted to have been active from the Noachian to the late Hesperian [Frey, 1979; Plescia and Saunders, 


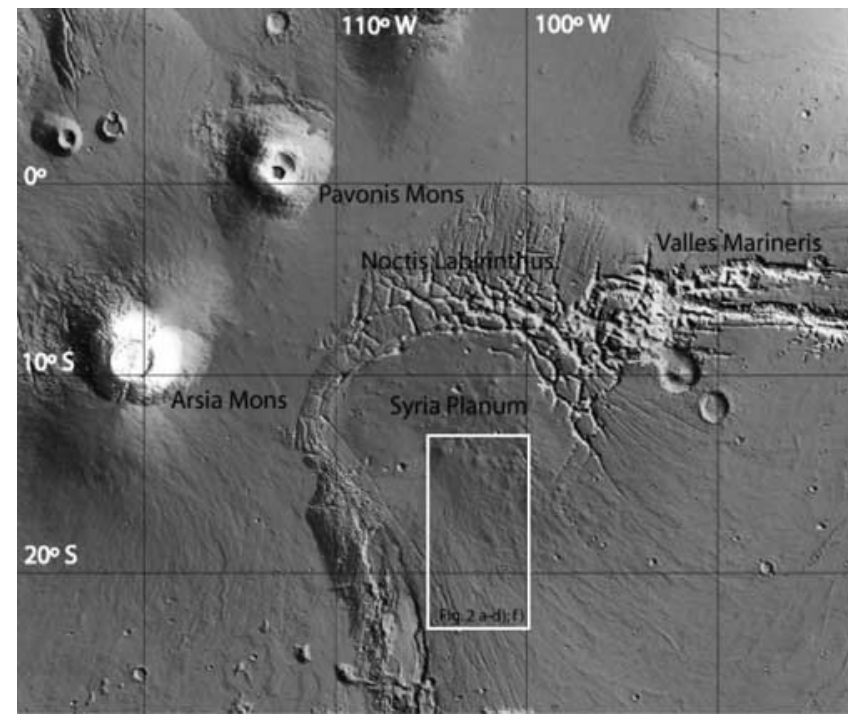

Figure 1. Shaded relief map from MOLA $1 / 128^{\circ}$ DEM. The white rectangle delineates the THEMIS mosaic of Figures $2 a-2 c$ and the maps obtained from HRSC and THEMIS mosaics in Figures $2 \mathrm{~d}$ and $2 \mathrm{f}$.

1982; Anderson et al., 2001]. Anderson et al. [2004] proposed that the long-lived magmatic activity of Syria Planum was related to a distinct episode of intensive tectonic activity during the late Noachian/early Hesperian, which declined and transitioned into a more volcanic style of activity [Dohm et al., 2001]. Scott and Wilson [2003] suggested that Syria Planum is essentially representative of an end-member of the volcanic history of the Tharsis dome, involving the loss of a volcanic root followed by consequent uplift and then final subsidence.

[4] The topographic map [Zuber et al., 1998] obtained by MOLA shows that Syria Planum is not a flat plateau (Figure 1). Webb et al. [2001] and Sakimoto [2003] noted the presence of topographic protuberances in MOLA data that might correspond to low shield volcanoes, although no image could confirm this interpretation. Now the HRSC images from the Mars Express orbiter allow us to identify and characterize these features at a high resolution (up to $10 \mathrm{~m} / \mathrm{pixel}$ ) and large coverage ideal for volcanic systems (Figure 2). Our study characterizes the volcanic landforms of this region, which appear to be much more developed than previously recognized. We identify and characterize a swarm of small shield volcanoes in terms of its origin, morphology, and periodicity of eruption, which we suggest requires further detailed study, namely, to understand its relationships with the complex history of the Tharsis bulge. In addition, a larger shield volcano is also identified on Syria Planum. We report on estimates of the rheological properties of the Syria Planum lava flows, their age, duration, morphology, and chronological relation to the smaller shield volcanoes.

\section{Data}

[5] We used high-resolution images acquired by the HRSC camera (orbits 2021, 2032, and 2054), orthorectified in a sinusoidal projection centered at $100^{\circ} \mathrm{W}$ longitude, with a resolution of $15 \mathrm{~m} /$ pixel. We mosaicked them to cover the region included in Figure 1 (the white box), where the swarm of shield volcanoes is observed (Figure 2e). This mosaic of images allowed us to identify, map, and extract morphometric parameters of the volcanic features. We also used MOLA data at a resolution of $128 \mathrm{pixel} /$ degree, about $500 \mathrm{~m}$ at the equator [Smith et al., 2001], and a vertical precision around $35 \mathrm{~cm}$ [Zuber et al., 1998] that have been rectified in the same projection as HRSC images to obtain altimetry (Figure 2a). The altimetry allowed us to determine the quantitative geometric shape of the shield volcanoes and lava flows. In addition, we used visible and thermal infrared (IR) images (mosaic of images I17865001, I17290014, I17552023, and I16953015) acquired by the spectrometer Thermal Emission Imaging System (THEMIS) during day or night with a spatial resolution of $100 \mathrm{~m} /$ pixel [Christensen, 2003]. The IR day and IR night data give the surface brightness temperature, which is relevant to the discussion of surface rock properties. Mosaics of IR day (Figure 2b) and IR night (Figure 2c) images were coregistered with the HRSC image coverage to observe the field of lava flows southwest of the shield volcanoes (white box in Figure 1). All these data allowed us to identify, map, and define the morphology, geometry, and age of the volcanic features of Syria Planum to propose a volcanic scenario in relation to the Tharsis region.

\section{Identification of the Main Morphostructural Units}

[6] The plateau of Syria Planum is about $450 \times 700 \mathrm{~km}$ wide and is centered at $12^{\circ} \mathrm{S}, 104^{\circ} \mathrm{W}$ (Figure 1). It is separated from the Tharsis Montes volcanoes by Noctis Labyrinthus to the north and Claritas Fossae to the west [Masson, 1980; Tanaka and Davis, 1988; Head et al., 2000]. On the basis of Viking images, Syria Planum has

\footnotetext{
Figure 2. (a) MOLA altimetry with height contour intervals of $50 \mathrm{~m}$. Regionally, the topography decreases from the north to the south and from the east to the west. (b) THEMIS IR day images (I17865001, I17290014, I17552023, and I16953015) where the white rectangles place and localize the figures shown in this work. (c) THEMIS IR night images. (d) MOLA slope expressed in percent. Some ruptures of slope are observed on the northwest and southwest, evidence for the presence of oriented fractures. The axisymmetrical protuberances on the northeast show higher dip mainly on their western flanks. Note the $20 \mathrm{~km}$ diameter protuberances on the higher (from about 6.8 to $7.5 \mathrm{~km}$ altitude) lands of Syria Planum. (e) Mosaic of HRSC images (orbits 2021, 2032 and 2054). (f) Geomorphologic map of Syria Planum. The axisymmetrical protuberances (morphostructure 1) are in red with impact craters in brown. The lava flows (morphostructure 2) that follow the regional slope are represented in orange. These formations are dissected by two families of lineations in black. On the southern part, these lineations become wider (morphostructure 3). In blue, at the top, we can distinguish some features that are the result of collapsed terrain. In gray possible contours for the top of the volcano A are represented.
} 


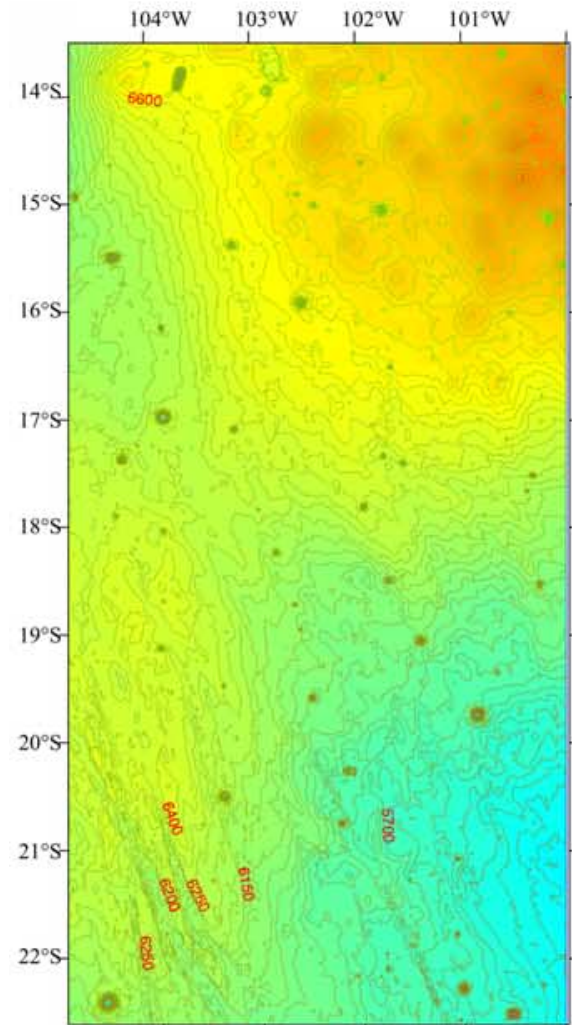

a) ${ }_{\text {Kilometers height interval: } 50 \mathrm{~m}}^{104^{\circ} \mathrm{W}} \quad{ }^{103^{\circ} \mathrm{W} \quad 102^{\circ} \mathrm{W} \quad 101^{\circ} \mathrm{W}}$ $104^{\circ} \mathrm{W} \quad 103^{\circ} \mathrm{W} \quad 102^{\circ} \mathrm{W} \quad 101^{\circ} \mathrm{W}$

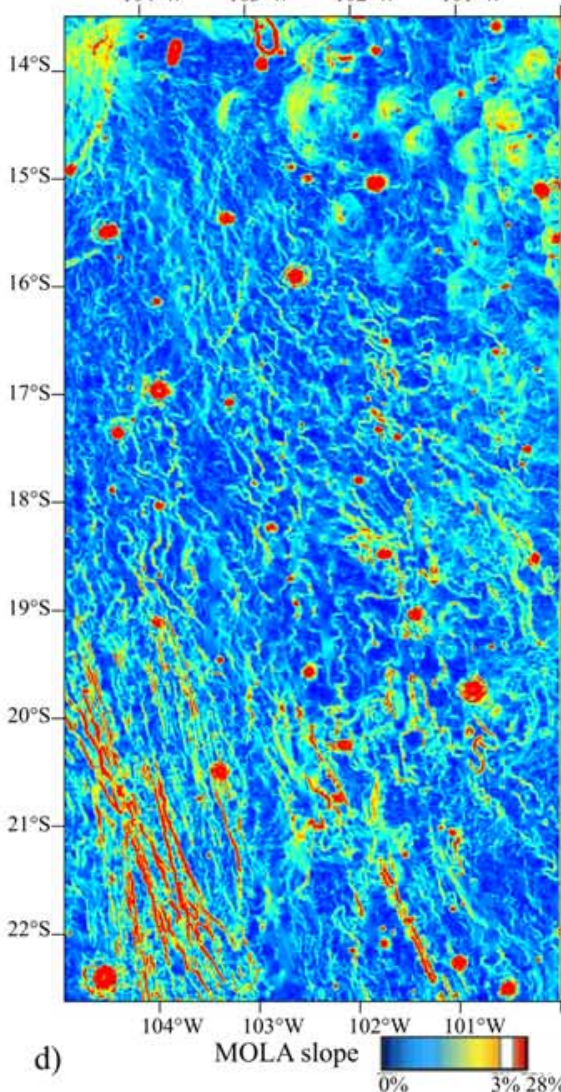

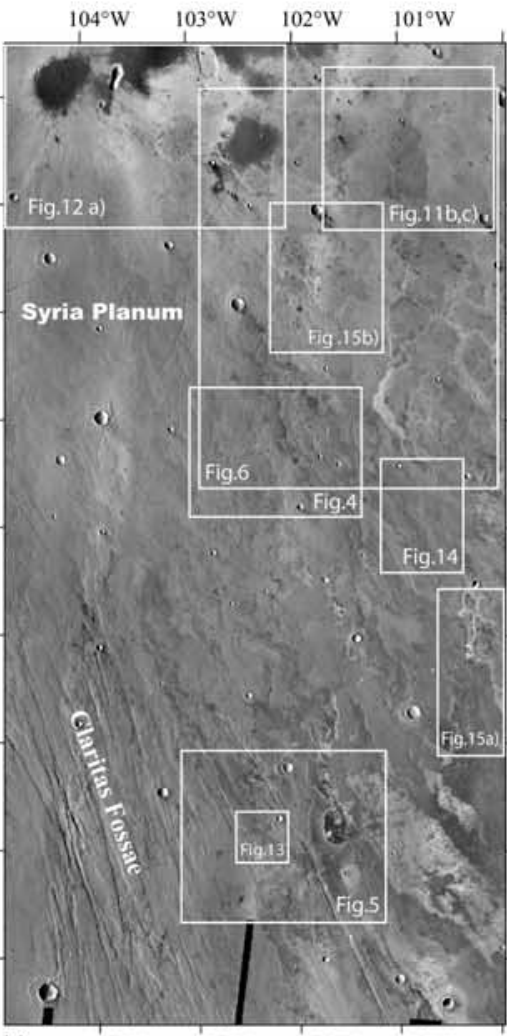

b) $104^{\circ} \mathrm{W} \quad 103^{\circ} \mathrm{W} \quad 102^{\circ} \mathrm{W} \quad 101^{\circ} \mathrm{W}$

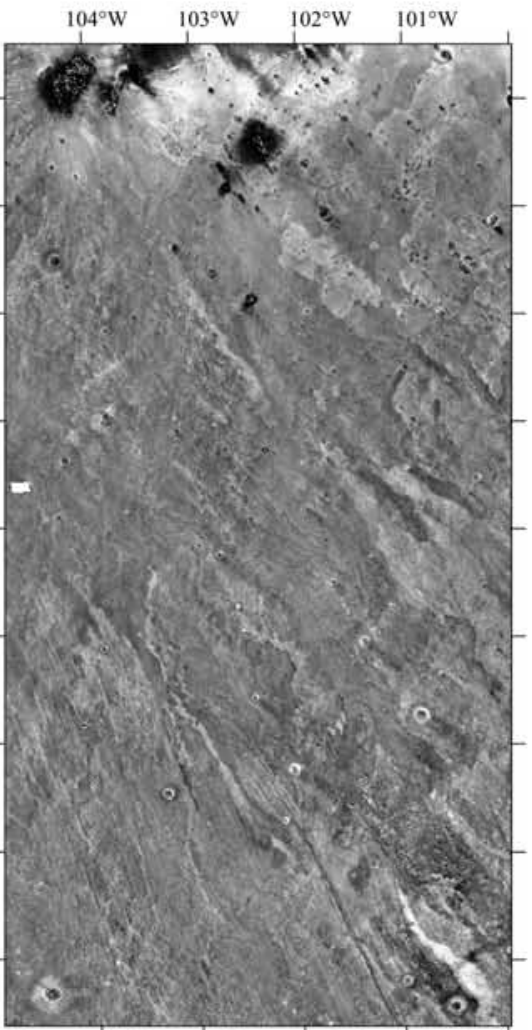

c) $104^{\circ} \mathrm{W} \quad 103^{\circ} \mathrm{W} 102^{\circ} \mathrm{W} \quad 101^{\circ} \mathrm{W}$

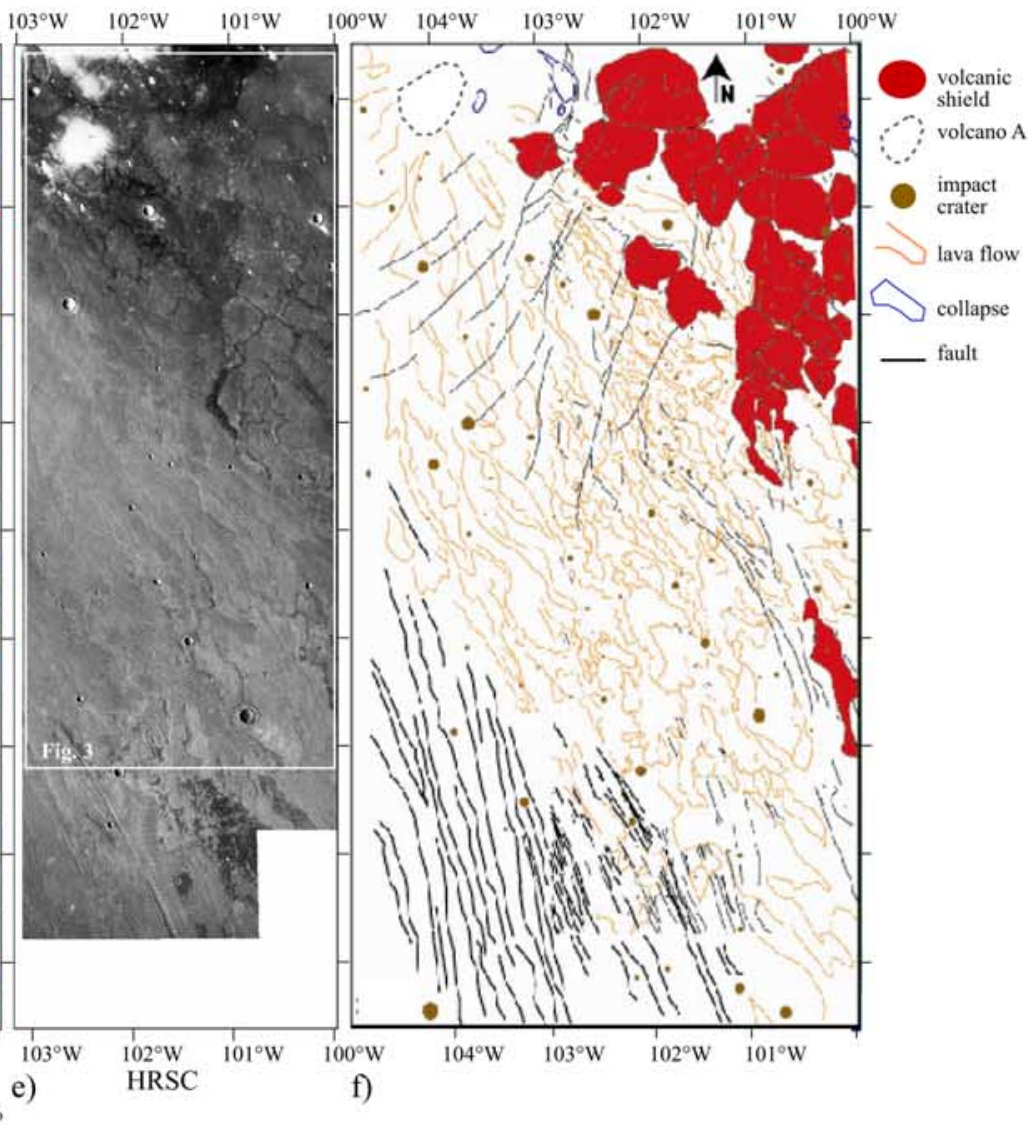

Figure 2 


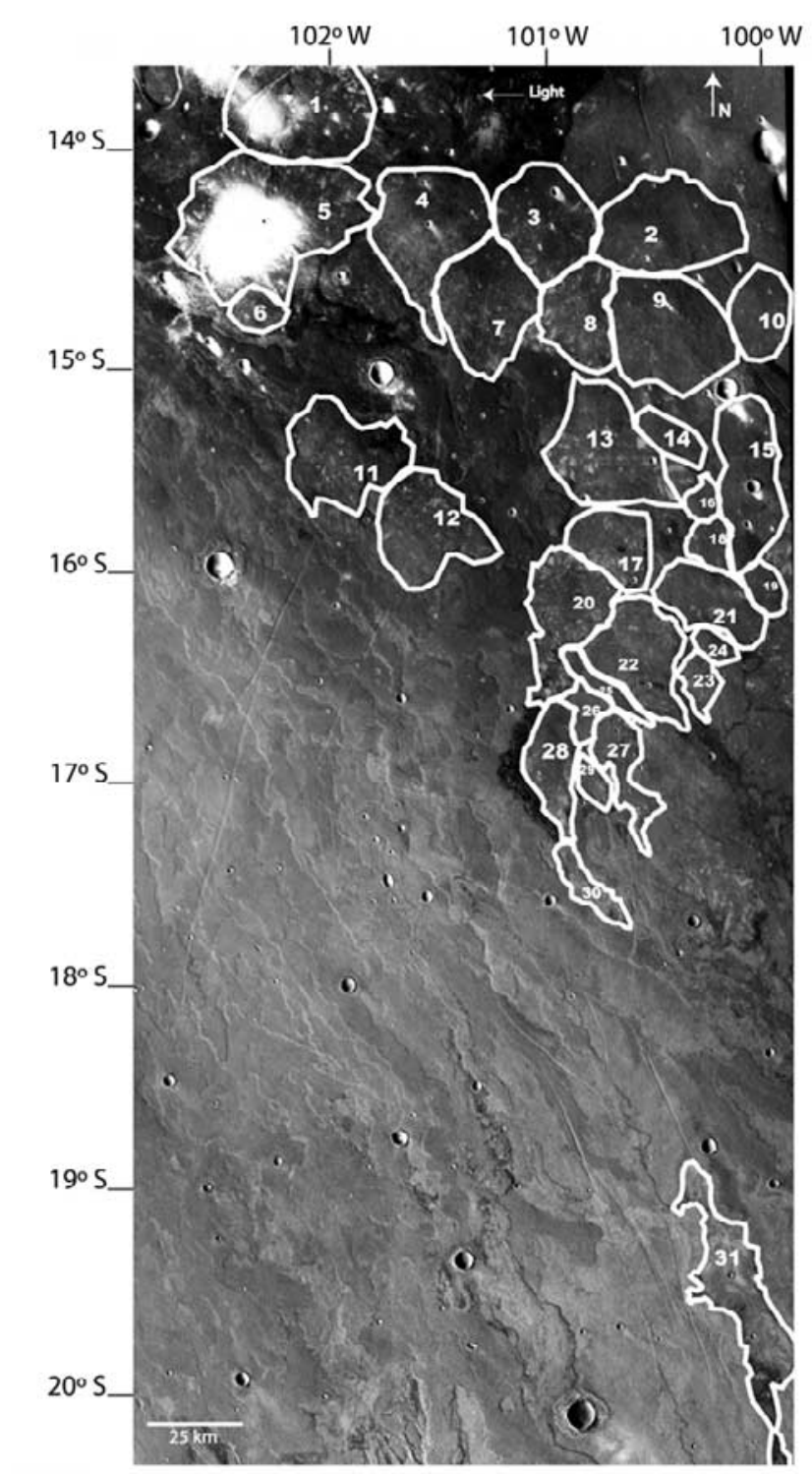

Figure 3. HRSC mosaic of the Syria Planum studied region. The context of this area is shown on Figure 2e. The higher albedo surfaces show areas highly covered by dust, while the lower albedo surfaces reveal contours of some circular features (on the East), extensive lava flows (coming from the Northwest), and two families of faults, more visible on the southern terrains. Several impact craters are also distinguished. Each single circular protuberance is circumscribed by a white contour and numbered (see Table 1).

been mapped as a volcanic plain of Hesperian age, with lava flows interpreted to originate from both the summit area and the flanks of a topographic high in northern Syria Planum and Noctis Labyrinthus [Tanaka and Davis, 1988; Scott and Tanaka, 1998]. Syria Planum also displays radial volcanic flow patterns [e.g., Tanaka and Davis, 1988] and volcanic eruptions along tube- fed and vent-fed flows [e.g., Chadwick et al., 2004; Webb et al., 2001]. Within this tectonovolcanic province, possible small edifices were locally found using Viking images [Hodges and Moore, 1994]. Some possible edifices are more broadly observed using MOLA altimetry
[Webb et al., 2001; Sakimoto, 2003]. They were named "protuberances" because of the lack of good imagery to certify the volcanic origin. These landforms stand at elevations $>6 \mathrm{~km}$ and are several tens of kilometers in diameter and several hundreds of meters high (Figure 2a).

[7] New images allow us to better characterize the landforms observed in Syria Planum. Figure 2 shows mosaics of THEMIS and HRSC images and a simplified geomorphic map drawn from these mosaics. We detail hereinafter the following three main morphostructural units deduced from these data and mapped in the simplified geomorphic map: (1) in the northern and eastern regions, a group of conical features that resemble small volcanoes and correspond to the protuberances seen on MOLA data; (2) in the western and central regions, extensive lobate shaped lava flows; and (3) in the southern region, a highly fractured terrain displaying graben-like structures.

[8] In the NE region of Syria Planum, HRSC and THEMIS images show a group of 10 to $60 \mathrm{~km}$ diameter, relatively circular features corresponding to the topographic protuberances seen in the MOLA map (Figure 2a). This swarm of protuberances displays a distinct pattern of coalesced landforms, as seen on Figures 3, 6, and 11, (between $12^{\circ}-21^{\circ} \mathrm{S}$ and $96^{\circ}-100^{\circ} \mathrm{W}$ ). A total of 30 individual protuberances are identified on these images (Table 1). They stand at the highest elevations on the plateau $(>7 \mathrm{~km}$ ). Some of these protuberances (e.g., numbers 1 and 5) located to the northern edge of the swarm have a higher albedo, interpreted as a dust cover, as confirmed by the low brightness in THEMIS IR night images (Figure 2c). Using the MOLA slope map expressed in percentage (Figure 2d), we observe that these protuberances have a central axisymmetry slope less than 3\%, indicating shallow slope cones. Some protuberances display a central vent or radial fractures (Figures $2 \mathrm{f}$ and 3 ). The combination of topography and imagery suggests that these topographic protuberances correspond to small volcanic edifices. We studied these landforms and discuss in section 4 how our results evidence this volcanic interpretation.

[9] In the central part of the HRSC image mosaic (Figure 3), we observe an intermediate albedo feature, $\sim 10 \mathrm{~km}$ wide and $>100 \mathrm{~km}$ long, with elongated shapes bounded by lobate fronts and scarps covering a widespread area oriented NW-SE. In THEMIS day IR, these landforms are characterized by an intermediate albedo with lobate shapes. These landforms are interpreted as lava flows that erupted from the NW of Syria Planum and flowed to the SE as indicated by the location of their lobate fronts. Their NW-SE trend is parallel to the SE regional topographic slope of $0.5 \%$ in this part of Syria Planum (Figures 2a and 2d). These lava flows stand between 5.4 and $6.8 \mathrm{~km}$ in altitude. They are poorly cratered and crosscut by tens of kilometers long, $2.5 \mathrm{~km}$ wide $\mathrm{N}-\mathrm{S}$ trending linear fractures (Figure 4).

[10] On the southernmost part of the HRSC image mosaic (Figure 5), below altitudes of $5.4 \mathrm{~km}$ on the MOLA map, the lava flows are crosscut by a widespread field of NWSE-trending grabens. In contrast to their smooth surface at the HRSC image scale, the darkest areas located eastward in Figure 5 correspond to rough bedrock that lava flows did not cover.

[11] In addition to these three main units, we observe that a few grabens cross both the protuberances (inferred small 
Table 1. Morphometric Parameters of Some Small Volcanoes in Syria Planum ${ }^{\mathrm{a}}$

\begin{tabular}{|c|c|c|c|c|c|c|c|c|}
\hline Volcano & $\begin{array}{c}\text { W-E Width } \\
(\mathrm{km})\end{array}$ & $\begin{array}{c}\text { Mean Slope } \\
\left({ }^{\circ}\right)\end{array}$ & $\begin{array}{l}\text { Altitude } \\
(\mathrm{m})\end{array}$ & $\begin{array}{c}\text { Mean Relief } \\
(\mathrm{m})\end{array}$ & Area $\left(\mathrm{km}^{2}\right)$ & $\begin{array}{c}\text { Mean Volume } \\
\left(\mathrm{km}^{3}\right)\end{array}$ & Vent & Eccentricity \\
\hline 1 & 41 & 0,7 & 6965 & 133 & 1081 & 55,7 & yes & 0,7 \\
\hline 2 & 40,9 & 1,0 & 7264 & 248 & 794 & 103,6 & yes & 0,4 \\
\hline 3 & 28 & 0,5 & 7060 & 117 & 637 & 22,8 & yes & 0,4 \\
\hline 4 & 32 & 0,6 & 7053 & 195 & 836 & 49,9 & yes & 0,5 \\
\hline 5 & 50,4 & 0,7 & 7085 & 241 & 1431 & 152,7 & yes & 0,5 \\
\hline 6 & 16,2 & 0,7 & 6933 & 81 & 139 & 5,3 & no & 0,4 \\
\hline 7 & 28 & 0,6 & 6999 & 105 & 704 & 20,5 & yes & 0,5 \\
\hline 8 & 19 & 0,7 & 7208 & 151 & 459 & 13,6 & yes & 0,5 \\
\hline 9 & 31,4 & 0,8 & 6999 & 202 & 839 & 49,8 & no & 0,5 \\
\hline 10 & 16,5 & 0,7 & 7208 & 110 & 318 & 7,5 & no & 0,4 \\
\hline 11 & 32 & 0,5 & 6955 & 70 & 686 & 17,9 & yes & 0,8 \\
\hline 12 & 29,5 & 0,4 & 6901 & 105 & 638 & 22,9 & no & 0,4 \\
\hline 13 & 29 & 0,5 & 7113 & 118 & 927 & 24,8 & yes & 0,8 \\
\hline 14 & 14 & 0,3 & 7051 & 30 & 157 & 1,5 & no & \\
\hline 15 & 14 & 0,7 & 7059 & 87 & 630 & 4,3 & yes & \\
\hline 16 & 9 & 0,4 & 7002 & 29 & 78 & 0,6 & yes & 0,4 \\
\hline 17 & 22,4 & 0,4 & 6977 & 77 & 363 & 9,6 & yes & \\
\hline 18 & 10,4 & 0,3 & 6920 & 36 & 131 & 1,0 & no & \\
\hline 19 & 9,6 & 0,7 & 6961 & 94 & 118 & 2,2 & yes & \\
\hline 20 & 23 & 0,6 & 6901 & 117 & 600 & 15,5 & yes & 0,7 \\
\hline 21 & 59 & 0,2 & 6858 & 50 & 444 & 43,5 & no & \\
\hline 22 & 26,4 & 0,3 & 6788 & 27 & 570 & 4,7 & yes & \\
\hline 23 & 10 & 0,5 & 6712 & 59 & 120 & 1,5 & yes & 0,6 \\
\hline 24 & 10 & 0,5 & 6657 & 40 & 264 & 1,0 & yes & 0,6 \\
\hline 25 & 7 & 0,3 & 7045 & 31 & 161 & 0,4 & no & \\
\hline 26 & 10 & 0,1 & 6737 & 10 & 112 & 0,2 & yes & \\
\hline 27 & 11 & 0,5 & 6763 & 57 & 270 & 1,7 & yes & 0,8 \\
\hline 28 & 14,5 & 0,4 & 6703 & 90 & 346 & 4,7 & yes & 0,9 \\
\hline 29 & 8,5 & 0,3 & 6628 & 67 & 82 & 1,2 & no & \\
\hline 30 & 8,7 & 0,2 & 6421 & 9 & 158 & 0,2 & no & \\
\hline
\end{tabular}

${ }^{\mathrm{a}}$ Averaged values of slope, relief, and volume were determined considering separately the northern, southern, western, and eastern flanks. In some cases, not all of the four orientations were measured. For the volcanoes 14, 17, 18, 21, 26, 28, 29, and 20 the northern slope and relief values were not considered for the mean slope average. Also, the eastern values of volcanoes $15,19,21$, and 29 were not considered. The difficulty in measuring some of the flanks is due to the superposition of lavas from adjacent volcanoes, which obviously hides the real contours of each volcano. The volumes were calculated using $V=1 / 3 \times \pi$ $r^{2} h$, where $h$ is the average relief and $r$ is half of the W-E width. Topographic data and images were used to determine the contact between the shields and the plains and the shape of this contact was then used to determine the eccentricity.

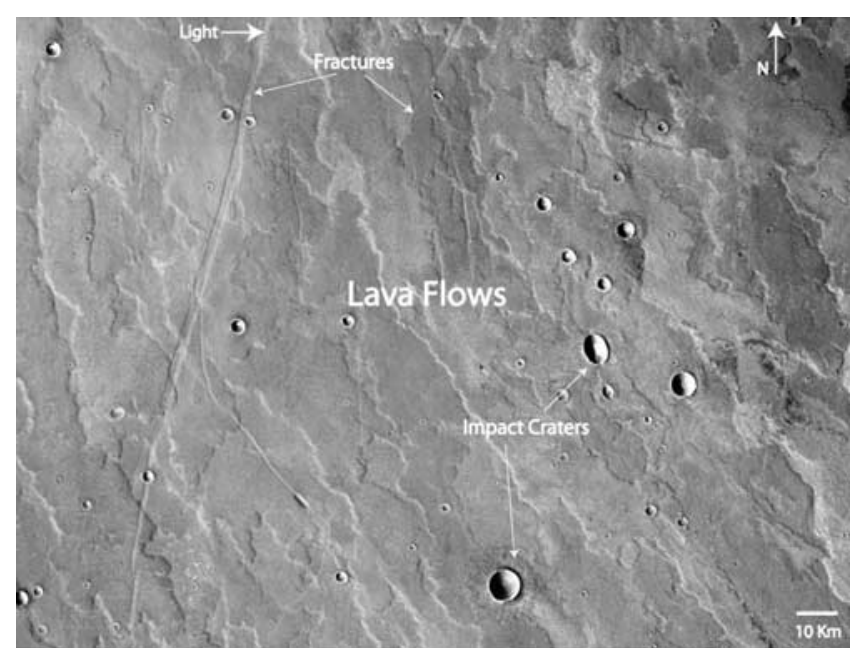

Figure 4. HRSC mosaic showing lava flow contours displayed in orange on Figure 2f. These lavas have a lobate and elongated shape, mainly oriented from NW to SE. Some of these flows are intersected by several lineations or faults. Illumination comes from the east. The image is centered at $\sim 18.5^{\circ} \mathrm{S}, 102.7^{\circ} \mathrm{W}$. See context on Figure 2 .

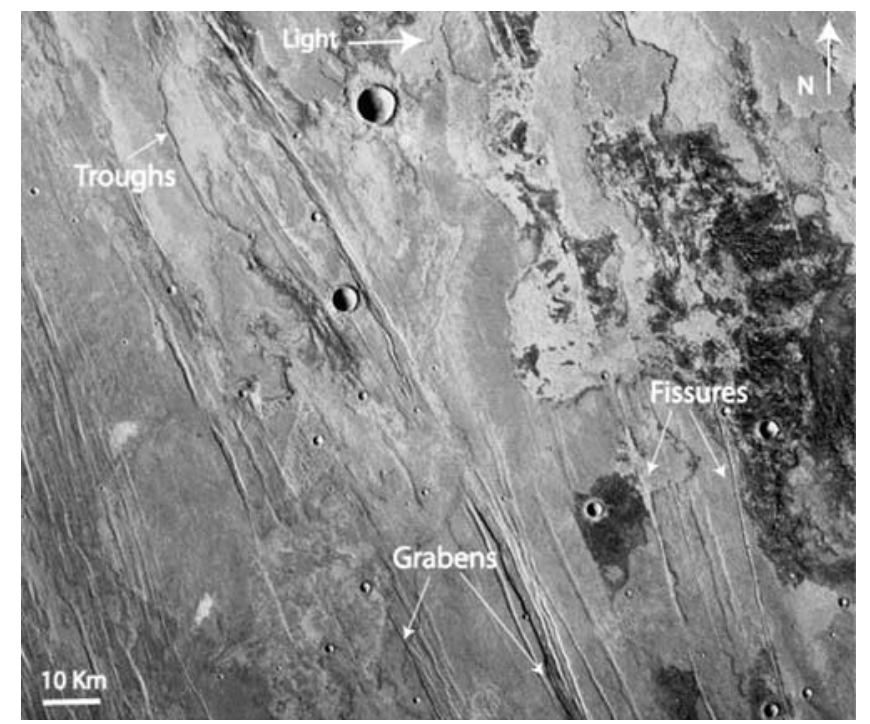

Figure 5. HRSC mosaic image showing several fractured lavas. Troughs are observed to be surrounded or filled in by lava. These fractured lava terrains show grabens of about $4 \mathrm{~km}$ width and several fissures that may be the result of ancient faults activated by volcanism. The image is centered at $\sim 20.5^{\circ} \mathrm{S}, 101.5^{\circ} \mathrm{W}$. See context on Figure 2. 

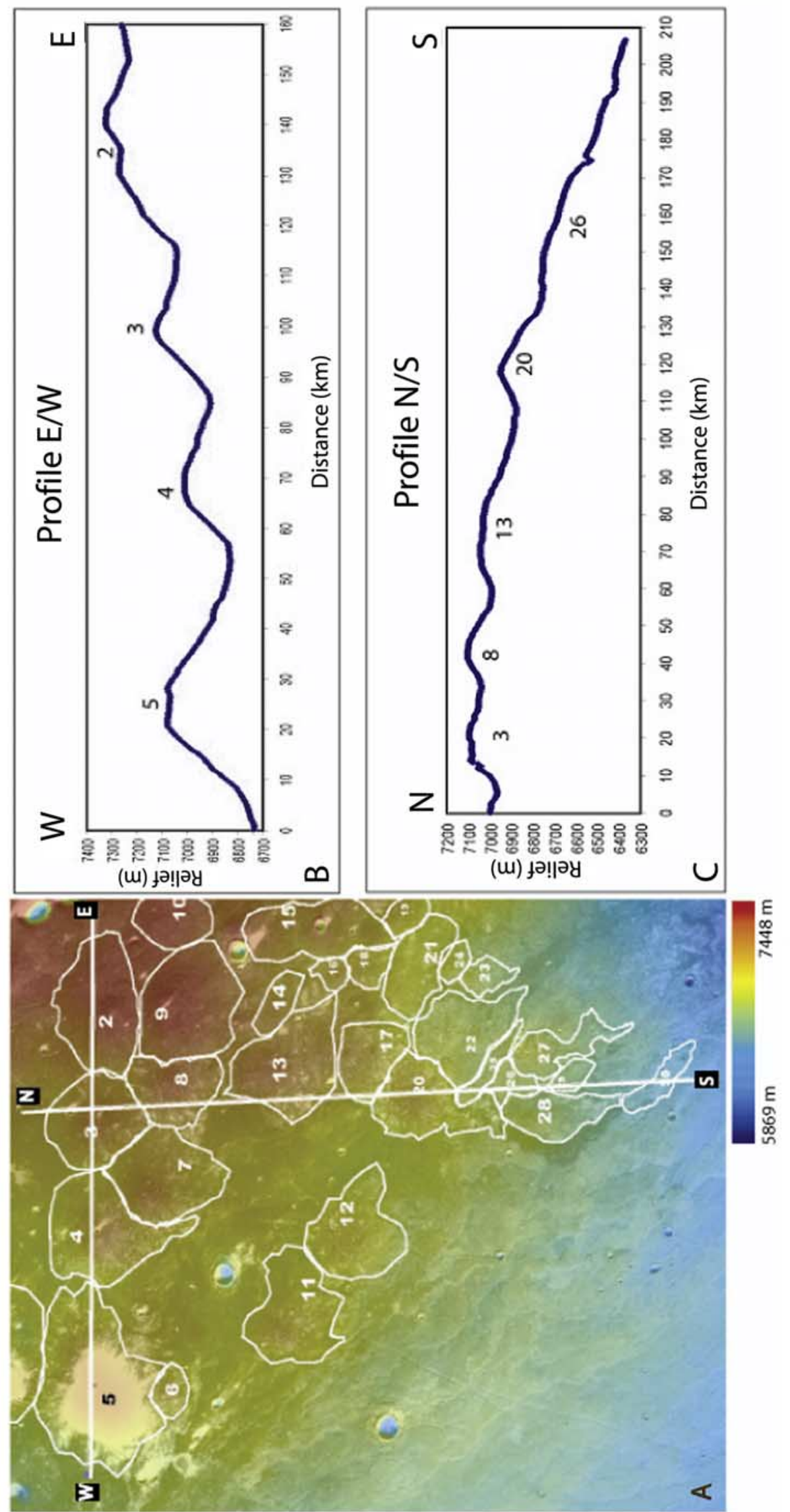

靬

可

흘 홍

23 要

需利

论

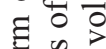

究造

के

$\exists=$

苛完

흐음

융 워

$\stackrel{3}{2} \frac{n}{2}$

?

응

․ㅖ

苕

$\pm$

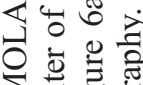

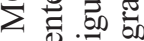

ธี 0.

过 on

实宊

으응

믐

की

舟

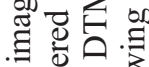

ن

彭

不

()ㅠ छี

$\circ \div 4$

D氙

就语 

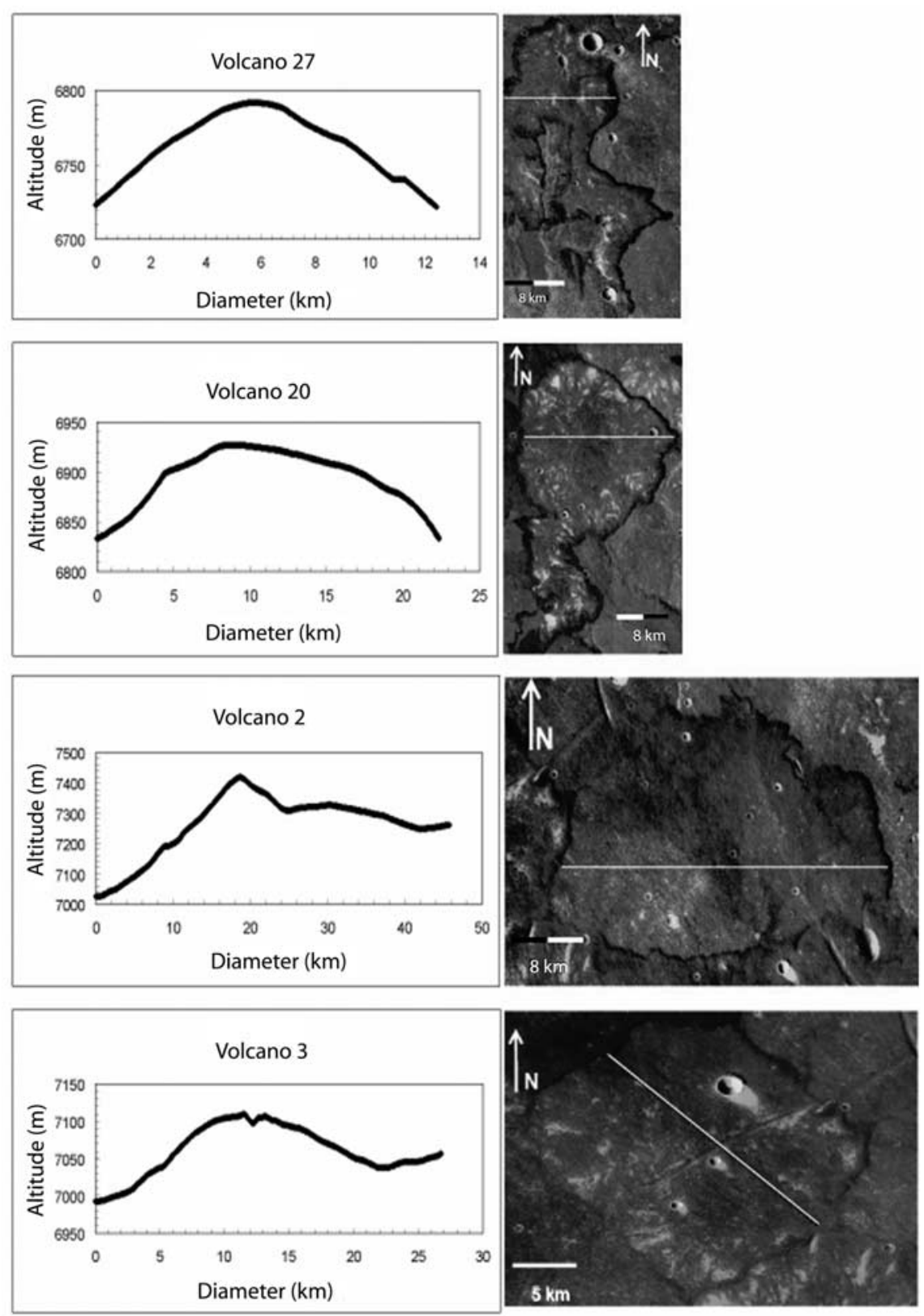

Figure 7. Detail of some shield volcanoes on Syria Planum as seen by HRSC and their correspondent profile from west to east (illumination from west). From the top to the bottom, we can see that volcanoes 27 and 20 show a $\mathrm{N}-\mathrm{S}$ elongated shape, and volcano 2 shows different flank slopes from west to east. Volcano 3 shows a vent on its summit, which crosses its section NE-SW.

shields) and the lava flows. Ovoid depressions, apparently resulting from a collapsed surface, exist on the top west and east at the external margins of the plateau. A large number of impact craters are also visible from a few tens of meters to $\sim 10 \mathrm{~km}$ diameter.

\section{Characteristics and Origin of the Axisymmetrical Protuberances}

\subsection{Morphometry of the Protuberances}

[12] The swarm of protuberances covers an area of about $250 \mathrm{~km}(\mathrm{~N}-\mathrm{S}) \times 150 \mathrm{~km}(\mathrm{E}-\mathrm{W})$ (Figure 3). It is likely that other cones might exist east of the studied region because similar structures are observed with THEMIS and MOLA data. However, we limit our characterization to the features observed in HRSC images.

[13] The HRSC images outline the extent of each axisymmetrical landform, showing their individual shapes (Figures 3 and 6). The topographic profile of each protuberance observed in the MOLA data coincides with the imagery, except for some protuberances located at the northern edge of this area that are covered by dust (numbers 1 and 5 on Figure 3). A predominant central fissure is also present on most of these landforms (e.g., numbers 3 and 27 on Figure 6). This fissure is inferred to be a vent, similar to those observed on terrestrial volcanoes. 


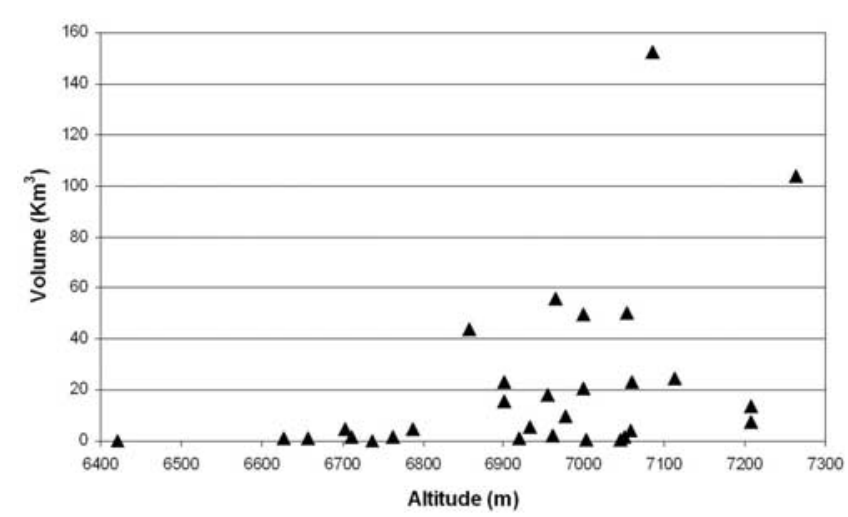

Figure 8. Distribution of Syria Planum small shield volcanoes volumes according to their summit altitude. There is a general tendency for the volcanoes with higher volumes of lava to concentrate at higher altitudes.
[14] These protuberances have flat conical shapes with basal diameters from 7 to $\sim 60 \mathrm{~km}$ and individual heights from 10 to $250 \mathrm{~m}$ (measured using MOLA data). The flank slopes of the individual features are between $0.2^{\circ}$ and $1.0^{\circ}$, with a median slope at $0.5^{\circ}$ (see Table 1$)$.

[15] The volume of the small shields $(V)$ was calculated, assuming a conical shape, using their average relief $(h)$ and their W-E basal width $(2 r)$ (Table 1): $V=1 / 3 \pi r^{2} h$. The volume of volcanic edifices ranges from 0.2 to $152.7 \mathrm{~km}^{3}$ (Table 1). These values should be considered lower bounds on the volume because many of the volcanoes may be embayed by younger materials such as lavas from the adjacent volcanoes and any loading phenomena would have compressed the volcanic material.

[16] Although these volcanoes usually have a conical shape, there are some exceptions. Some of them (e.g., numbers 13 and 20 on Figure 6) display slightly asymmetrical $\mathrm{E}-\mathrm{W}$ topographic profiles, with the steeper side often on the west. These steeper slopes occur at the intersection

\section{Mars Volcanoes Dimension}

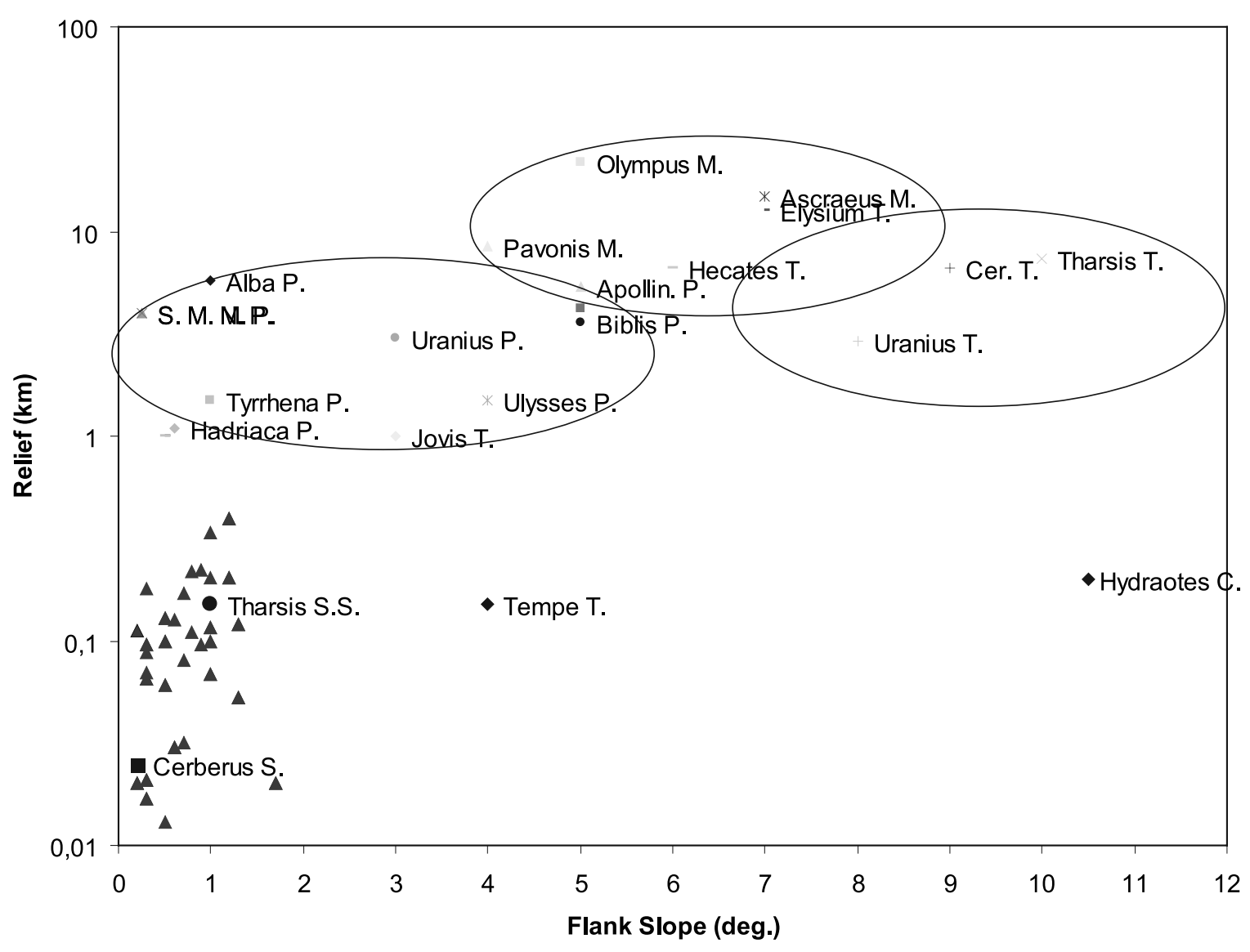

Figure 9. Dimension of Martian volcanoes. The highest topographies are dominated by the Tharsis Montes, while the Highland Paterae are characterized by their flatness [Plescia, 2004]. The highest volcano flank dip exists on the Tholii [Plescia, 2004] and on the little cones of Hydraotes Chaos [Meresse et al., 2008]. The Cerberus shields (symbolized by a rectangle) represent the smallest shield volcanoes observed on Mars [Vaucher et al., 2006] while those observed in Tempe Terra have higher thicknesses [Davis and Tanaka, 1993]. The Syria Planum small shield volcanoes (represented by the bigger triangles) are also flat and of low relief, similar to those shields observed close to the Tharsis Montes (symbolized by a small circle) [Bleacher et al., 2007]. 

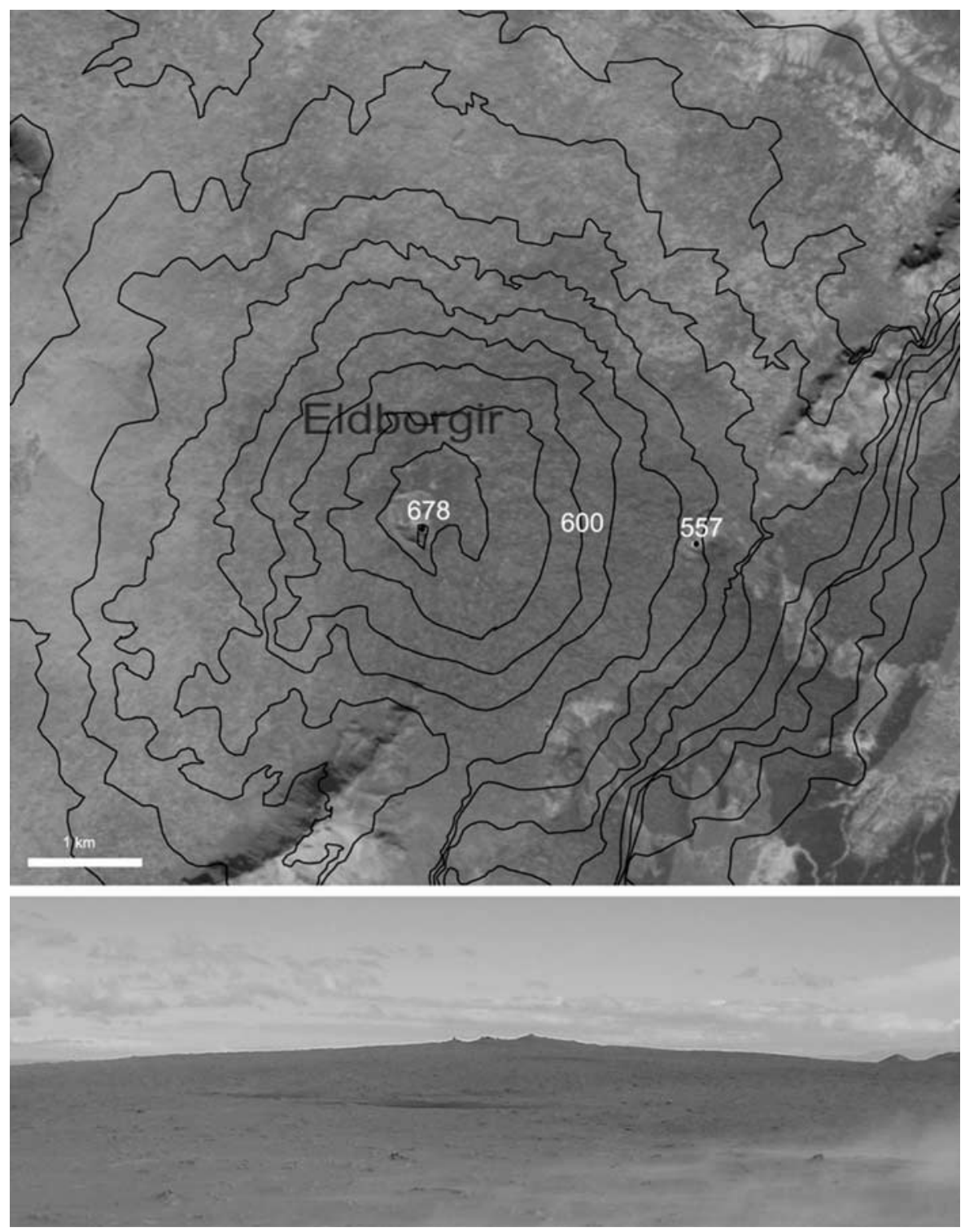

Figure 10. Icelandic small shield volcano. The volcano in the images is Eldborgir ((top) SPOT 5 satellite image with $20 \mathrm{~m}$ height contour intervals; (bottom) photography by authors), with a summit high of $200 \mathrm{~m}$ and a diameter of $\sim 1000 \mathrm{~m}$. Eldborgir is located in the south of Iceland in a periglacial cold desert area.

with the lava flows, as observed on our map of slopes (Figure 2d), whereas the volcanoes that are surrounded by other volcanoes tend to have a rounder shape and no preferential higher flank dip. Second, the volcanoes tend to be circular north of $15^{\circ} \mathrm{S}$ (Figure 7), but the shape can be $\mathrm{N}-\mathrm{S}$ elongated, following the regional topography (e.g., number 20 on Figure 8). We observe that these volcanoes tend to have elongated shapes with the decrease in the regional topography and, consequently, the increased regional slope below $6.5 \mathrm{~km}$. To support these observations, we tested the circularity of each volcano. The assessment of the circularity can be done using the eccentricity, a parameter of the distortion of a circle into an ellipse, which corresponds to the ratio of the linear eccentricity (square root of the difference between the square of the semimajor axis and the square of the semiminor axis) to the semimajor axis. To compute this, we extracted the altitude values of the largest closed contour (contours spaced of $20 \mathrm{~m}$ ) of each volcanic feature from the MOLA contour data. The results are shown in Table 1. The absence of results for volcanoes $14,15,17-19,21,22,25,26,29$, and 30 is due to their flatter surface; the limited vertical resolution of MOLA data does not permit the isolation of their contours. On the basis of these calculations, we observe that the northern volcanoes (e.g., numbers $2-10$ ) are rounder (eccentricity between 0.4 and 0.5 ) than the southern ones (e.g., numbers 13 , $20,23,24,27$, and 28), which tend to be more elongated (eccentricity between 0.6 and 0.9 ).

[17] Each volcano increases in slope in the E-W direction (as shown on the profiles of Figure 7). Over all Syria Planum, the volcanoes increase in volume in the $\mathrm{S}-\mathrm{N}$ direction, consistent with the increase in altitude (Figures 68). The slope increase to the west occurs closer to the units of large lava flows (e.g., number 5 on Figure 4 or Figure 7). 


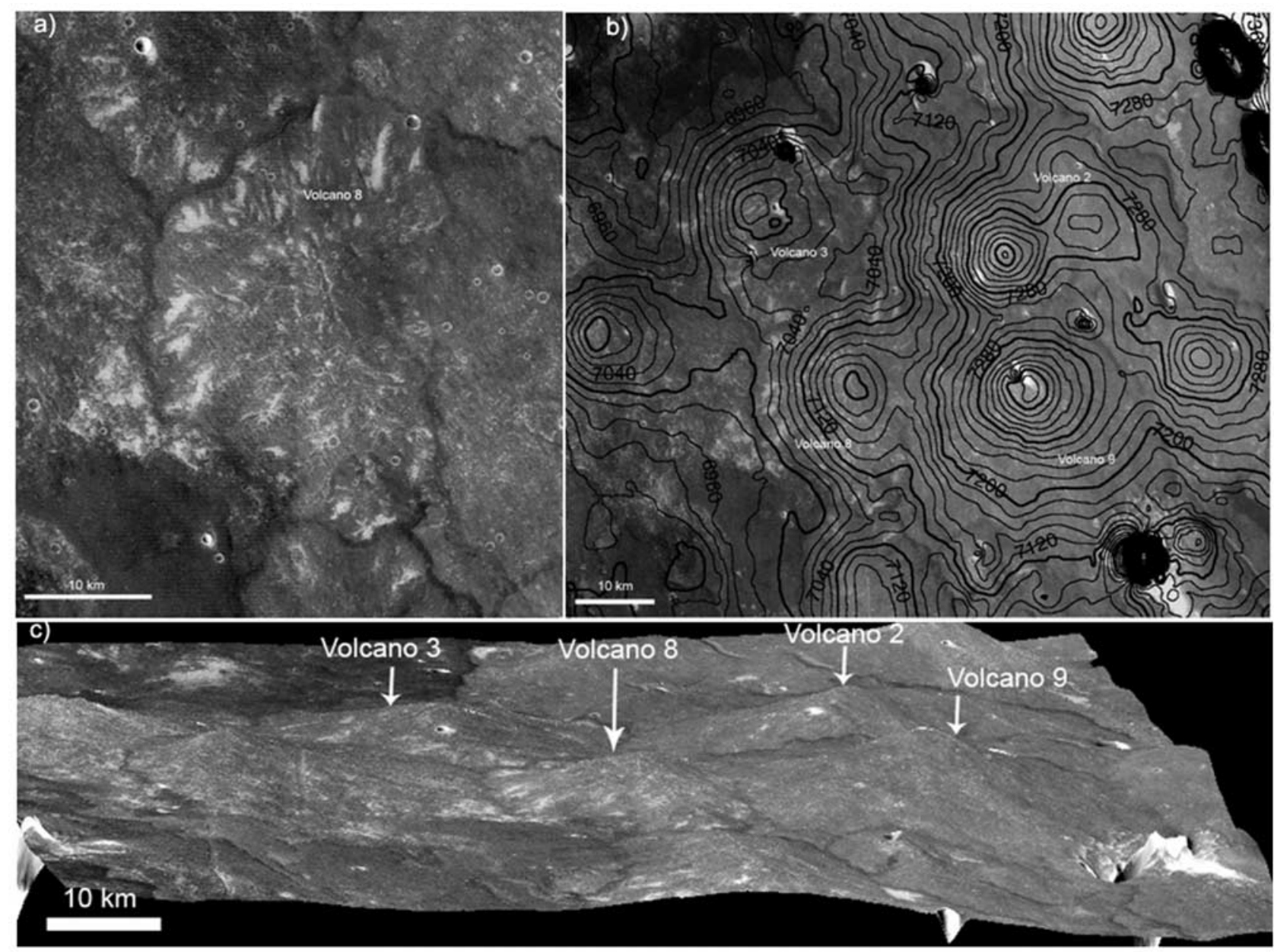

Figure 11. (a) Shield volcano 8 seen by HRSC, where a small vent is visible on the top. (b) HRSC image superimposed by MOLA data where the contour lines (spaced of $20 \mathrm{~m}$ ) delineate each volcanic shield. The field of coalesced shield volcanoes is represented in a 3-D picture, with $10 \mathrm{X}$ vertical exaggeration. (c). The elevation of volcanoes 2, 3, 8, and 9 is shown on Figures $11 \mathrm{~b}$ and $11 \mathrm{c}$.

The volume decrease to the south is correlated to a decrease of elevation and an increase of the slope (Figures 6-8). This might be due to the fact that the slope impedes the development of a (well-developed) circular volcano creating more elongated edifices. As a consequence, the volcanoes with higher volumes and more circular shapes occur in the northern region, where the terrains are flatter and the elevation reaches a maximum (e.g., numbers 2 and 3 on Figures 7 and 8 ).

[18] The protuberances have a significant variability in their size, shape, volume, and the existence of an observable vent, but they have the mean shape of a flat cone that can be interpreted as being formed by the progressive accumulation of lavas, similar to terrestrial small shield volcanoes. We next test this hypothesis through comparison with other Martian volcanoes and analogs on Earth.

\subsection{Comparison With Other Volcanoes on Mars and on Earth}

[19] Figure 9 displays a graph of height versus slope for the main Martian volcanoes and the small volcanoes of Syria Planum. The small volcanoes observed in Syria Planum are different from the three main classes of volca- noes on Mars [e.g., Plescia, 2004]. The Tharsis Montes, which display a higher relief $(>10 \mathrm{~km})$, are characterized by moderate slopes $\left(3-10^{\circ}\right)$ and broad collapse calderas at their summits [Malin, 1977]. Close to their flanks, low thickness shields with few kilometers in diameter can also be observed [e.g., Greeley, 1977, 1982; Hodges and Moore, 1994; Bleacher et al., 2007]. Tholii are smaller $(1-10 \mathrm{~km})$ than the Montes but they have steeper flank slopes $\left(7-12^{\circ}\right)$, much steeper than the Syria Planum volcanoes [e.g., Mouginis-Mark et al., 1992]. Highland Paterae have gentle slopes $\left(<5^{\circ}\right)$ with shallow relief $(1-8 \mathrm{~km})$ [e.g., Greeley and Crown, 1990]. By comparison, the Syria Planum small edifices have a shape distinct from the three main classes of Martian volcanoes. While they have slopes similar to those of the Paterae (but much smaller in size), they are unlikely to be similar in terms of spatial extent and temporal activity. Syria Planum edifices, therefore, correspond to a distinct class of volcano that we may compare to small edifices found in Cerberus or Tempe Terra [e.g., Hauber et al., 2007].

[20] Comparing the volume of erupted magma, Plescia [2004] determined values for the large Tharsis shields, like Olympus Mons $\left(2.4 \times 10^{6} \mathrm{~km}^{3}\right)$, Alba Patera $\left(1.8 \times 10^{6} \mathrm{~km}^{3}\right)$, 

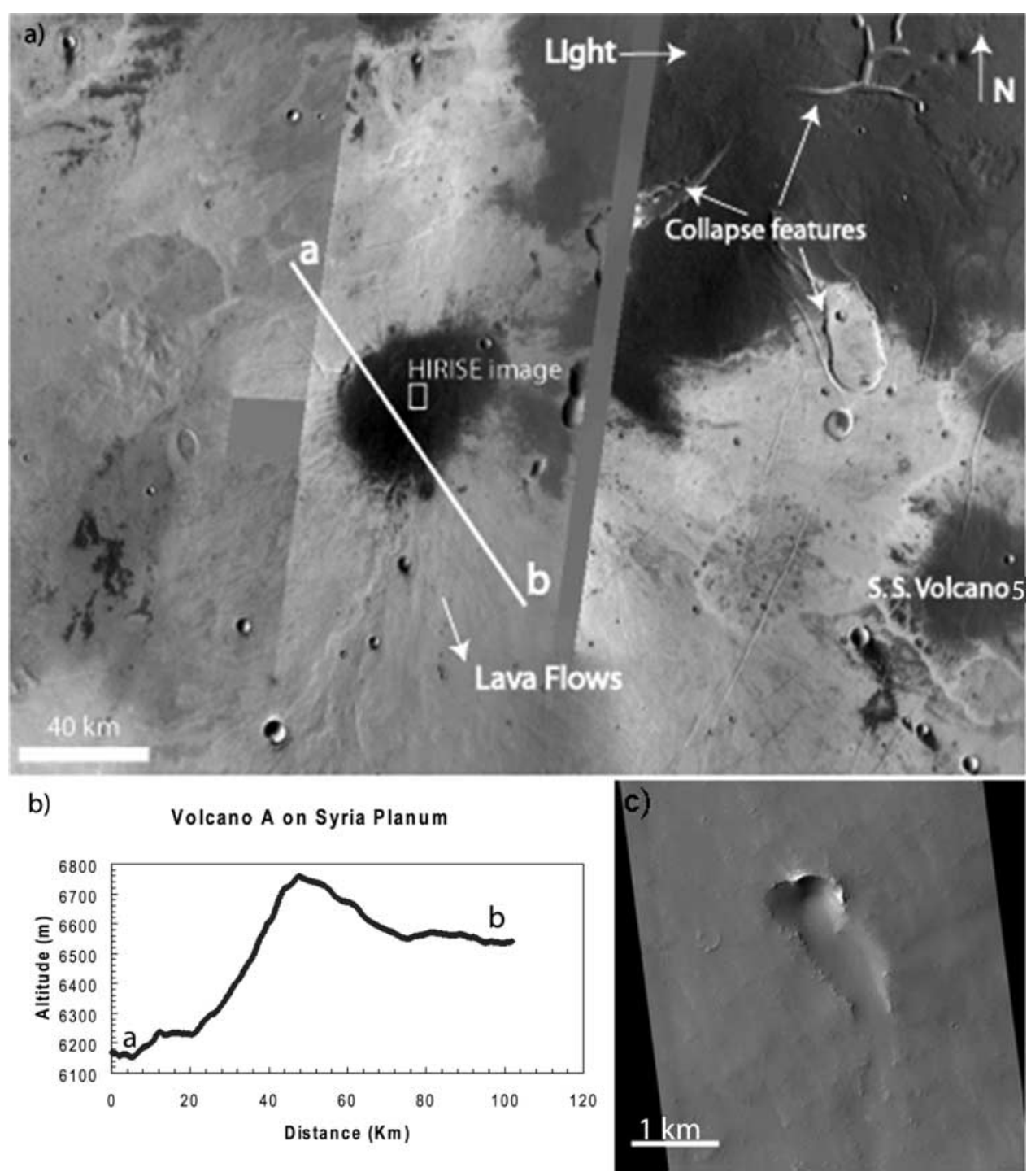

Figure 12. (a) On the center of this image one can observe volcano A, which is the eruption center of the described lava flows. The caldera is about $40 \mathrm{~km}$ wide. On the bottom right of the image the shield volcano 5 is visible. On the top right, several collapse features are noted. (b) The profile $a-b$. (c) HIRISE image (PSP_001840_1660) showing a volcanic vent, with about $700 \mathrm{~m}$ width, on the top of volcano A.

and Ascraeus Mons $\left(1.1 \times 10^{6} \mathrm{~km}^{3}\right)$. The other volcanoes are all in the order between $10^{3}$ and $10^{5} \mathrm{~km}^{3}$, with the exception of the Jovis Tholus $\left(10^{2} \mathrm{~km}^{3}\right)$, the minimum determined value. These volume amounts contrast with the Syria Planum small shields that are normally below $10^{2} \mathrm{~km}^{3}$.

[21] On Earth, similarly shaped small shield volcanoes are found in locations such as Iceland (Figure 10). Rossi [1996] presented a study of 24 basaltic postglacial shield volcanoes in Iceland. He found a median slope of $2.7^{\circ}$ (from $0.6^{\circ}$ to $8^{\circ}$ ), a median height of $60 \mathrm{~m}$ (from 12 to $520 \mathrm{~m}$ ), and a median diameter of $3.6 \mathrm{~km}$ (from $500 \mathrm{~m}$ to $11 \mathrm{~km}$ ). The shallow shape of these shields is due to the fluid lavas coming out of rift regions. Syria Planum cones can be compared to some of the Icelandic cones (Figure 11). A comparison is proposed with the Eldborgir shield volcano (also called Lambahraun), which formed 6000 years ago from a single long-duration eruption (Figure 10). The $10 \mathrm{~km}$-diameter volcano has a mean slope of $2^{\circ}$ with a summit vent. Its shape is not purely conical, as it formed over preexisting, nonflat topography.
Several Icelandic cones have slopes smaller than $2^{\circ}$, or even $1^{\circ}$, such as Strandarheið̄i with a slope of $0.6^{\circ}$ [Rossi, 1996], comparable to those of Syria Planum edifices. On average, the small edifices of Syria Planum have a median slope of $0.5^{\circ}$, thus 5 times smaller than in Iceland. A possible explanation of this difference is that it might come from a difference in viscosity of lavas slightly more fluid on Mars.

\section{Characterization of the Lava Flows Unit}

\subsection{Morphology and Lavas Origin}

[22] The extensive field of lava flows, identified between $\sim 15^{\circ}-19^{\circ} \mathrm{S}$ and $105^{\circ}-102^{\circ} \mathrm{W}$, covers an area of $\sim 100,000 \mathrm{~km}^{2}$ (Figure 2). Through the study of HRSC images and THEMIS IR day and IR night images, we can identify elongated and lobate shapes for these flows with preferential orientation NW to $\mathrm{SE}$, following the regional slope. 


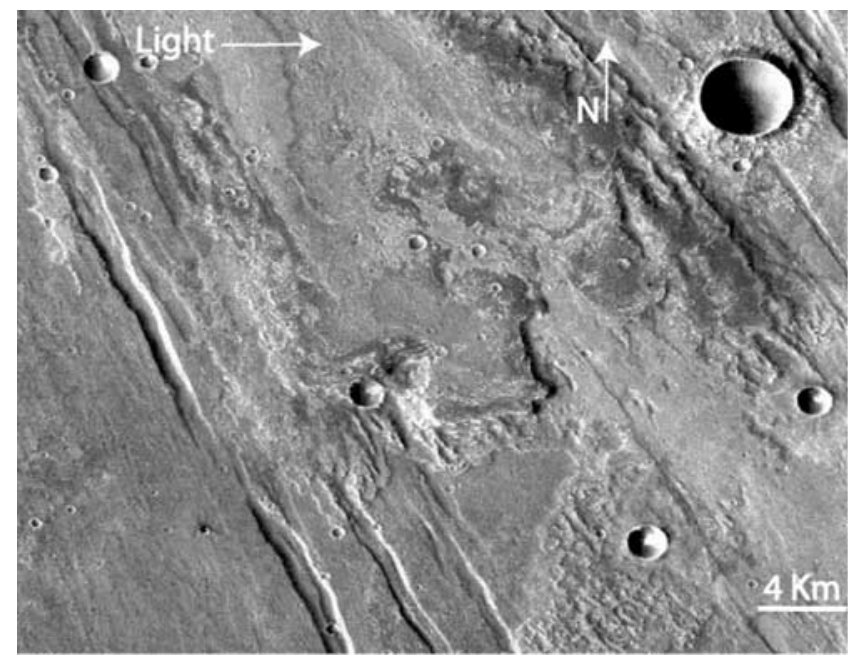

Figure 13. HRSC image centered at $20.5^{\circ} \mathrm{S}, 102.3^{\circ} \mathrm{W}$, where some NW-SE oriented grabens are covered by lavas with the same orientation.

[23] Using THEMIS and MOLA data, we observe that these lava flows erupted from an isolated volcano, hereinafter named volcano A, on the northeast of Syria Planum (Figure 12, represented on the geomorphic map on Figure 2f). The summit cone of volcano A is about $40 \mathrm{~km}$ in diameter, and it lies at an elevation of $\sim 6700 \mathrm{~m}$. This volcano is located outside of the HRSC mosaic, although a new High Resolution Imaging Science Experiment (HiRISE) image enables its study (Figure 12). On Figure 12, we show a MOLA profile from "a" to "b." From the center of the volcano to the side a the slope is about $1.4^{\circ}$, while from the center to the side $\mathrm{b}$ the slope decreases to $0.7^{\circ}$ to the side where the lava flows extend.

[24] We can observe the presence of postflow tectonic deformation. On Figure 12, note that the flanks facing east are much smoother than the western flanks, where the slope is much more accentuated. On the southern part of Syria Planum, and from an extension of some hundreds of kilometers SE of volcano A, we observe that the lava flows partially cover a field of grabens (Figure 13). We detail the fault system and its relationship with lava flows in section 6 .

\subsection{Lava Flow Rheology}

[25] Using HRSC images, THEMIS IR day and MOLA data, we studied several lobate lava flows on Syria Planum. The results from its geometry and rheology are shown in Table 2. It is largely known that Martian volcanic edifices can produce several features such as lava tubes and channels [e.g., Carr, 1973, 1974; Greeley, 1973; Greeley and Spudis, 1981; Cattermole, 1987, 1990; Sakimoto et al., 1997]. In terrestrial volcanology there exists a link between tube flows and a more steady flow rate and, conversely, the connection between channels and unsteady flow rates [e.g., Sakimoto et al., 1997].

[26] We infer the Syria Planum lava channels are predominantly the result of constructional processes (flow confined by building of levees), often roofing over to form tube flows. The lava channels occur in the area immediately south of the Syria Planum shield volcanoes (Figure 14), an area where several periods of intensive fracturing are recognized (as described in section 6).

[27] The techniques described below consider alternatively the lava flows as Newtonian fluids (which allows the determination of the flow rate and viscosity) or as Bingham flows characterized by a yield stress. These techniques are useful in providing a comparison between terrestrial flows (of known composition) and Martian lava flows [e.g., Hulme, 1976]. However, given the fact that these rheological models are mutually inconsistent, the computed absolute values should be viewed with extreme caution.

\subsubsection{Lava Flows Dimensions}

[28] We isolated 10 lava flows where channel (or tube) flows are mostly present and their rheology was studied using MOLA DTM data. The size of the observed lava flows varies from a few hundred meters to about $200 \mathrm{~km}$, with the mean length of about $150 \mathrm{~km}$. Their width varies from 5 to $15 \mathrm{~km}$, with the mean value of $9.4 \mathrm{~km}$. The levees on the lava flow have a mean width of $5 \mathrm{~km}$. Thicknesses of the lava flow vary from 15 to $70 \mathrm{~m}$, with a mean value of $34.5 \mathrm{~m}$. The average slopes of the studied flows are approximately to $0.2^{\circ}$, although in a few cases (in places with superposition of lavas) it can exceed $1^{\circ}$. This results in volumes of individual lava flows ranging from an average of $40 \mathrm{~km}^{3}$ to a maximum of $200 \mathrm{~km}^{3}$.

\subsubsection{Effusion Rate}

[29] The effusion rate of this system, or its volume flow rate $\left(Q, \mathrm{~m}^{3} \mathrm{~s}^{-1}\right)$, can be determined using the Graetz dimensionless number $(\mathrm{Gz})$ [e.g., Knudson and Katz, 1979; Pinkerton and Wilson, 1994; Warner and Gregg, 2003; Hiesinger et al., 2005]:

$$
Q=\frac{G z k x w}{b} .
$$

The Graetz number that is related to the cooling of a warm fluid moving through a cold pipe [Hulme and Fielder, 1977; Wilson and Head, 1983; Zimbelman, 1985] assumes laminar flow and relates the heat lost by diffusion in a flow to the heat lost by advection along its length [Warner and Gregg, 2003], in which $k$ is the thermal diffusivity $\left(3.0 \times 10^{-7} \mathrm{~m}^{2}\right.$ $\mathrm{s}^{-1}$, a similar value for both Martian and terrestrial lavas) [e.g., Gregg and Fink, 1996; Warner and Gregg, 2003], $x$ is the flow length (m), $w$ is the width of the flow (m), and $b$ is

Table 2. Geometric and Rheologic Parameters Measured From Topographic Data From Profiles on 10 Lava Flows

\begin{tabular}{lccccccc}
\hline & Length $(\mathrm{m})$ & Thickness $(\mathrm{m})$ & Width $(\mathrm{m})$ & Slope $\left(^{\circ}\right)$ & Effusion Rate $\left(\mathrm{m}^{3} \mathrm{~s}^{-1}\right)$ & Viscosity $(\mathrm{Pa} \mathrm{s})$ & Yield Stress $(\mathrm{Pa})$ \\
\hline Minimum & $45 \times 10^{3}$ & 15 & $5 \times 10^{3}$ & 0.15 & 990 & $6.89 \times 10^{5}$ & - \\
Maximum & $200 \times 10^{3}$ & 70 & $15 \times 10^{3}$ & 1 & 6,075 & $4.23 \times 10^{6}$ & - \\
Mean & $150 \times 10^{3}$ & 34.5 & $9.4 \times 10^{3}$ & 0.2 & 3,300 & - & $1.2 \times 10^{3 \mathrm{a}}$ \\
\hline
\end{tabular}

${ }^{\mathrm{a}}$ Lengths between 100 and $200 \mathrm{~km}$ and thicknesses between 15 and $70 \mathrm{~m}$ were used. The mean value for the smaller size lavas is $7.9 \times 10^{2}$ and $1.7 \times 10^{7}$ for the larger ones. 


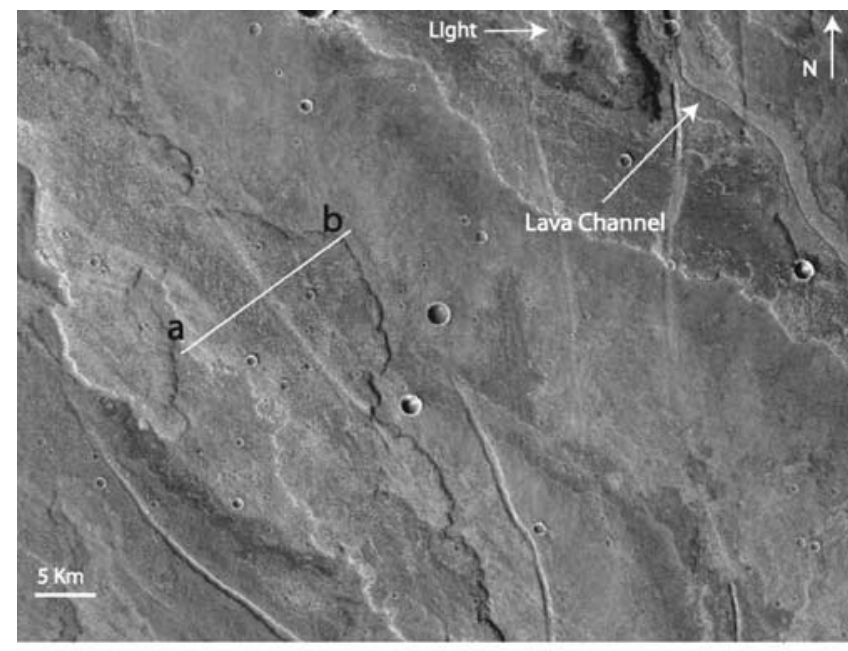

Lava Flows

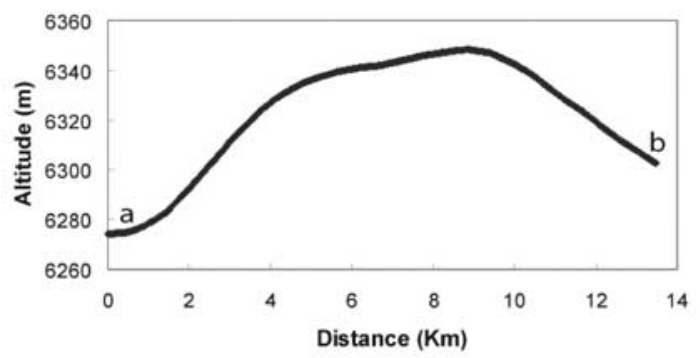

Figure 14. Image centered at $17.3^{\circ} \mathrm{S}, 100^{\circ} \mathrm{W}$. Lava channels are visible on the described lava flows. The channel on the top right displays lava levees on its sides. The profile $\mathrm{a}-\mathrm{b}$ is shown on the bottom graphic.

the thickness of the flow (m). In analogy to terrestrial lava flows, we assumed a value of 300 for the Graetz number [e.g., Hiesinger et al., 2005]. As a result, we find that effusion rates range from 990 to $6075 \mathrm{~m}^{3} \mathrm{~s}^{-1}$, and the mean value is $3300 \mathrm{~m}^{3} \mathrm{~s}^{-1}$. These values are the same order of magnitude as the ones determined for Arsia Mons [Warner and Gregg, 2003], although they are of some orders of magnitude superior to those found on Ascraeus Mons (18$60 \mathrm{~m}^{3} \mathrm{~s}^{-1}$ and a mean value of $35 \mathrm{~m}^{3} \mathrm{~s}^{-1}$ from Zimbelman [1985]) or on Olympus Mons ( $400 \mathrm{~m}^{3} \mathrm{~s}^{-1}$ from Zimbelman [1985]). Regarding the effusion rates and determining the volumes of individual lava flows, we calculated that the time necessary to emplace these flows is 140 days on average, with a maximum of 700 days.

\subsubsection{Viscosity}

[30] The viscosity can be determined using a model obtained from a steady laminar isothermal gravity-driven Newtonian flow, with no slip at the base and no shear stress at the top surface [Sakimoto et al., 1997]. This flow system can be resolved in a rectangular flow solution (equation (2)) where flow depth and flow width are comparable. The surface velocity is independent of the cross-flow direction, likewise because there are no channel walls [Sakimoto et al., 1997]. So, the flow rate per unit width is given by

$$
\frac{Q}{w}=\frac{b^{3} \rho g^{\prime} \sin (\theta)}{3 \mu} .
$$

Here $Q$ is the volume flow rate (i.e., eruption rate), $w$ is full flow width (in sheet flow), $b$ is the flow depth in a Newtonian channel and sheet flow, $g^{\prime}$ is the adjustment made for the acceleration of gravity on Mars $\left(3.73 \mathrm{~m} \mathrm{~s}^{-2}\right), \theta$ is the slope, $\mu$ the viscosity, and $\rho$ is the density (we assumed $2800 \mathrm{~kg} \mathrm{~m}^{-3}$, knowing that this value can change by $30-50 \%$ in the presence of bubbles/vesicles in lavas).

[31] Our estimate of the viscosity ranges from a minimum of $6.89 \times 10^{5} \mathrm{~Pa} \mathrm{~s}$ to a maximum of $4.23 \times 10^{6} \mathrm{~Pa} \mathrm{~s}$ (depending on the previous determined values of effusion rate). These values are in agreement with several other viscosities determined for Martian lavas [e.g., Hiesinger et al., 2005, 2007; Warner and Gregg, 2003]. On Earth, terrestrial basalts and andesites have viscosities from $1.4 \times$ $10^{2}$ to $1.4 \times 10^{7} \mathrm{~Pa}$ s [e.g., Hiesinger et al., 2005; Wilson, 2001; Wilson and Head, 1994]. So, the Syria Planum lava flows are in the range of relatively viscous basalt to andesite. Also, Fink and Zimbelman [1986], assembling different methods, determined values from $\sim 0.8 \times 10^{6}$ to $8 \times 10^{6} \mathrm{~Pa}$ s for the Kilauea lava flows.

\subsubsection{Yield Stress}

[32] Alternatively, we consider below that the lava flows can be approximated using Bingham fluids, which differ from Newtonian fluids by the existence of yield strength in addition to the viscosity.

[33] The yield stress may be estimated from the combination of the following three parameters: the flow depth $b$, the slope $\theta$, and the width of the flow $w$, and also by assuming a density flow value equivalent to terrestrial basalt $\left(2800 \mathrm{~kg} \mathrm{~m}^{-3}\right)$ [e.g., Hiesinger et al., 2005]:

$$
\begin{gathered}
\sigma_{s}=\rho g b^{2} / w \\
\sigma_{s}=\rho g b \sin \theta .
\end{gathered}
$$

Using equations (3) and (4), for 10 lava channels of Syria Planum with lengths between 100 and $200 \mathrm{~km}$ and thickness between 15 and $70 \mathrm{~m}$, we obtain mean values between $7.9 \times 10^{2} \mathrm{~Pa}$ (for the smaller sizes) and $1.7 \times$ $10^{3} \mathrm{~Pa}$ (for the larger sizes), and the overall mean value is $1.2 \times 10^{3} \mathrm{~Pa}$. These values are consistent with terrestrial basaltic to andesitic lava flows and also with the Arsia Mons lavas [see Moore et al., 1978]. Also, Zimbelman [1985] determined similar values for Arsia Mons (1.0 \pm $\left.0.8 \times 10^{3} \mathrm{~Pa}\right)$ and larger values for Ascraeus Mons $(2.1 \pm$ $\left.1.8 \times 10^{4} \mathrm{~Pa}\right)$ and Olympus Mons $\left(2.0 \pm 0.3 \times 10^{4} \mathrm{~Pa}\right)$. Fink and Zimbelman [1986] determined different values of viscosity depending on the place that the measurements were made along the lava flow; higher with the increasing distance to the lava source. These authors analyzed lavas from the Kilauea volcano, in which lavas have lengths inferior to $3 \mathrm{~km}$, so they have inferior size to the Martian ones, and obtained values from $\sim 4 \times 10^{3}$ to $40 \times 10^{3} \mathrm{~Pa}$.

[34] Overall, rheologic parameters from Hawaiian and Arsia Mons flows are about the same order of magnitudes of those determined in Syria Planum.

\section{Tectonic Patterns and Their Relationship With Volcanic Units}

[35] In the studied area, we identify at least four tectonic episodes distinguishable from their different directions and 


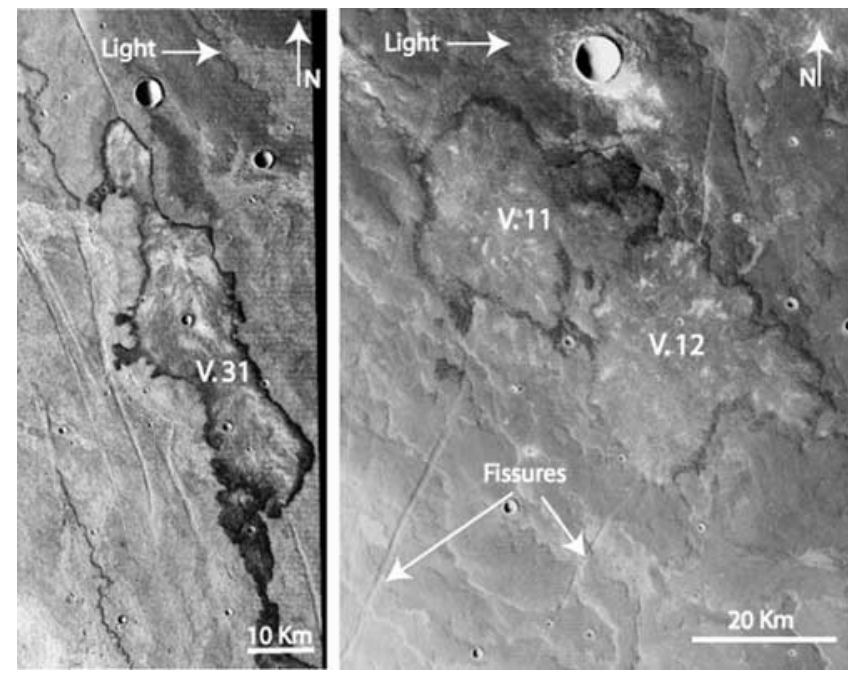

Figure 15. (left) HRSC image centered approximately at $19.8^{\circ} \mathrm{S}, 100.9^{\circ} \mathrm{W}$ showing the volcano 31 , a fissure some tens of kilometers long from which lavas erupted. Its borders, which have a clearly darker tone, define well its shape. (right) $\mathrm{HRSC}$ image centered at $15.4^{\circ} \mathrm{S}, 101.5^{\circ} \mathrm{W}$, where volcanoes 11 and 12 superimpose lavas that were intersected by fissures oriented NE-SW.

patterns. First, using MOLA and HRSC data, we observe NW-SE faults typically a few kilometers wide and hundreds of kilometers long, as seen at the bottom of the studied images (Figures 2 and 13). These fractures exhibit a very dense network of faults defining many small grabens, which are covered by lava flows related to volcano $\mathrm{A}$ in the northwest. These grabens might correspond to the most primitive tectonic pattern that affected the bedrock previously to the discussed volcanic events. Syria Planum was the center of tectonic activity before the emplacement of the volcanic plains at the surface. Those older faults are observed in Claritas Fossae and north of Noctis Labyrinthus. Presumably those faults underlie the present surface and can exhibit control on the area's volcanism.

[36] Second, the lava flows of volcano A have been intersected by faults, mainly oriented $\mathrm{NE}-\mathrm{SW}$, in the northern region of Syria Planum (Figure 15, right). We determine that these fractures are hundreds of kilometers long and approximately some tens of meters in depth. They are much more scattered and less densely distributed than the NW-SE oriented faults found to the south.

[37] Third, in the southern and eastern regions of Syria Planum (Figure 15, left), next to the NW-SE oriented grabens, there are fissures some hundreds of meters wide. Volcano 31 appears to have been created by such NW-SE reactivation. This activity thus clearly postdates the lava flows of volcano A and, therefore, the NW-SE faults that are buried beneath the lava flows. We interpret these faults and related activity to have resulted from a reactivation of the ancient NW-SE fractures possibly as a consequence of volcanic activity. It can be seen from the chronological relationships that the overall $\mathrm{NW}-\mathrm{SE}$ features were formed earlier (without relation to this volcanic episode) and buried beneath lava flows from volcano $\mathrm{A}$, whereas individual faults in same direction found over the lava flows formed later, probably in relation to the formation of the small shields.

[38] Finally, one can also identify several collapsed features (represented in blue on the geomorphologic map of Figure $2 \mathrm{f}$ ) in the proximity of the isolated volcano A (Figure 12) and structural depressions that extend laterally to volcano 2 (e.g., Figure 3). These collapse features postdate all the different terrains of Syria Planum, affecting the small shields at their northern boundary.

[39] These four types of tectonic patterns can result from different volcanotectonic activities [e.g., Masson, 1980]. Faults with NW-SE preferential orientation correspond to the Noachian-Hesperian graben construction [e.g., Plescia and Saunders, 1982; Tanaka and Davis, 1988]. This activity is related to the first episode of faulting to the south, corresponding to a major stress field that crossed most of the Tharsis region. Faults with a NE-SW trend are more scattered, resembling individual fissures rather than a main tectonic episode. It has been shown that such features can be produced by near-surface stress fields associated with intrusive magma, which can fill in the existing fractures and sometimes increase their dimensions [e.g., Wilson and Head, 1981; Tanaka and Davis, 1988]. Because of the proximity of the small shield volcanoes, these faults might be interpreted as dikes from which several volcanic edifices were created. The ancient $\mathrm{NW}-\mathrm{SE}$ fault direction might have been reactivated, possibly at the same time as the NESW faults formed, to localize the emplacement of the elongated volcanoes such as number 31 . The collapse features that crosscut all units might be related to the period of main collapse of the Noctis Labyrinthus region north of Syria Planum.

[40] Chronologically, the sequence of tectonic and volcanic activity is very clear from relative stratigraphy. If we interpret the collapse features to have formed during the Noctis Labyrinthus event, then the age of these collapses would correspond to approximately the end of the late Hesperian and beginning of the early Amazonian [Tanaka and Davis, 1988]. This suggests that the volcanoes were all formed prior to that period. In the next section, we test this possibility by dating the volcanoes using crater counts.

\section{Dating Volcanoes by Crater Counts}

[41] Craters larger than $250 \mathrm{~m}$ in diameter were counted and classified over a surface of $7760 \mathrm{~km}^{2}$ corresponding to the small shield volcanoes and over $20,945 \mathrm{~km}^{2}$ on the lava flows. For the volcanoes, the craters were first counted for each isolated volcano and then summed over the entire surface in order to be able to date them both individually and as a whole.

[42] The cumulative number of impact craters with diameter $\geq 1 \mathrm{~km}$ is

$$
N(1)=\frac{N}{S} \pm \frac{\sqrt{N}}{S}
$$

where $N$ is the number of craters per surface $S$. We determined $0.0029 \pm 0.0006$ craters $\mathrm{km}^{-2}$ for the small shields and $0.0025 \pm 0.0003$ craters $\mathrm{km}^{-2}$ for the lava flows. These counts correspond to ages of 3.5-3.6 Ga for small 


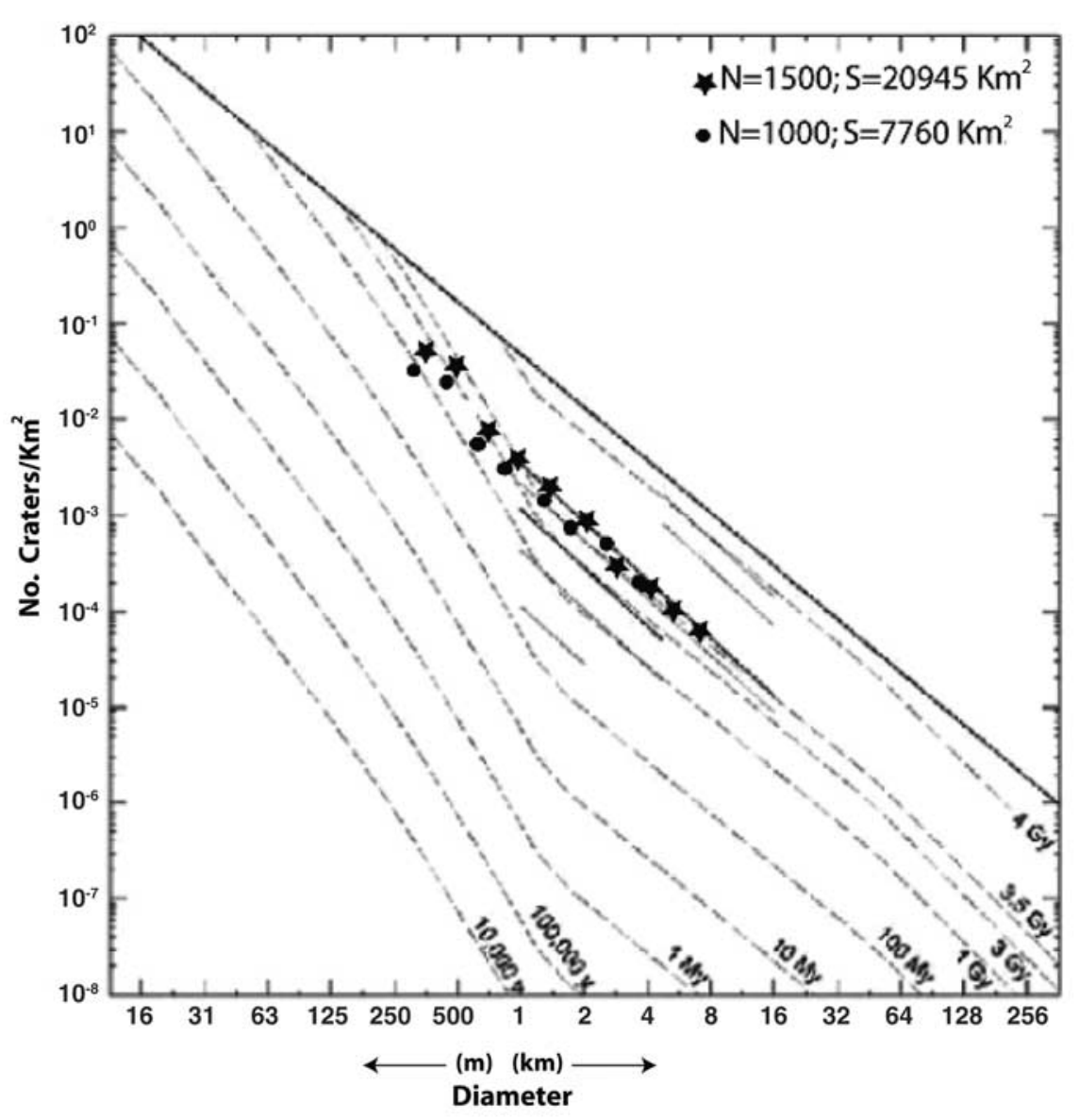

Figure 16. Crater distribution over the studied Syria Planum lava flows and shield volcanoes. Isochrones are plotted according to Hartmann et al. [2000]. We used only craters $>250 \mathrm{~m}$ diameter for this study. The ages associated with the isochrones are given by the lunar rates modulated by a ratio of $R=1.6$, corresponding to the ratio between the crater production function on Mars and the same rate on the Moon. However, these could all correspond to Hesperian ages. Dots correspond to volcanoes ages associated with a surface of $7760 \mathrm{~km}^{2}$ and where $\sim 1000$ impact craters with a diameter $>250 \mathrm{~m}$ were observed. Stars correspond to lava flow ages associated with a surface of $20945 \mathrm{~km}^{2}$, where $\sim 1500$ impact craters with a diameter $>250 \mathrm{~m}$ were observed.

shields and $\sim 3.6 \mathrm{Ga}$ for the lava flows from volcano A [Hartmann and Neukum, 2001]. The ages are not significantly different, suggesting that the period of time between the formation of volcano $\mathrm{A}$ and the small shields was limited.

[43] For a more accurate estimation, we plotted ages in increments of $\sqrt{2}$, as in the model of Hartmann and Neukum [2001]. The isochrones plotted on Figure 16 correspond to the density of craters that should be observable on a surface preserved from erosion and deposition since its formation.

[44] The model takes into account the crater production function of the Moon, adapted for Mars, which fixes the slope of craters smaller than $1 \mathrm{~km}$ and is adapted to show turndowns and variations of populations that could be interpreted in terms of obliteration, erosion, or deposition [Hartmann et al., 2000]. On Figure 16, one can observe the frequency of each interval of crater size for the volcanoes (in dots) and for the lava flows (in stars). Both units follow isochrones of the Hesperian period with small shields appearing slightly younger than the lavas. The more recent ages for craters $<500 \mathrm{~m}$ correspond, therefore, to surface degradation because of resurfacing since the formation of lava.

[45] We next tried to individually date each volcano, although statistically this estimate is not valid once recent resurfacing processes obliterate the smaller craters. The smaller-sized craters may be a good indicator of resurfacing and erosion periods, whereas to date bedrock (not surface) processes, the bigger sizes (up to $250-350 \mathrm{~m}$ ) are better.

[46] The dating of these volcanoes, as well as their topographic analyses, confirm previous propositions [Plescia, 2004] of the fact that they might have occurred during a geologically short period of time, probably not more than some tens of millions of years. From this work, and using HRSC images and MOLA data on crater counting, we assume that these events may have lasted from the early Hesperian to the middle of the Hesperian, which 


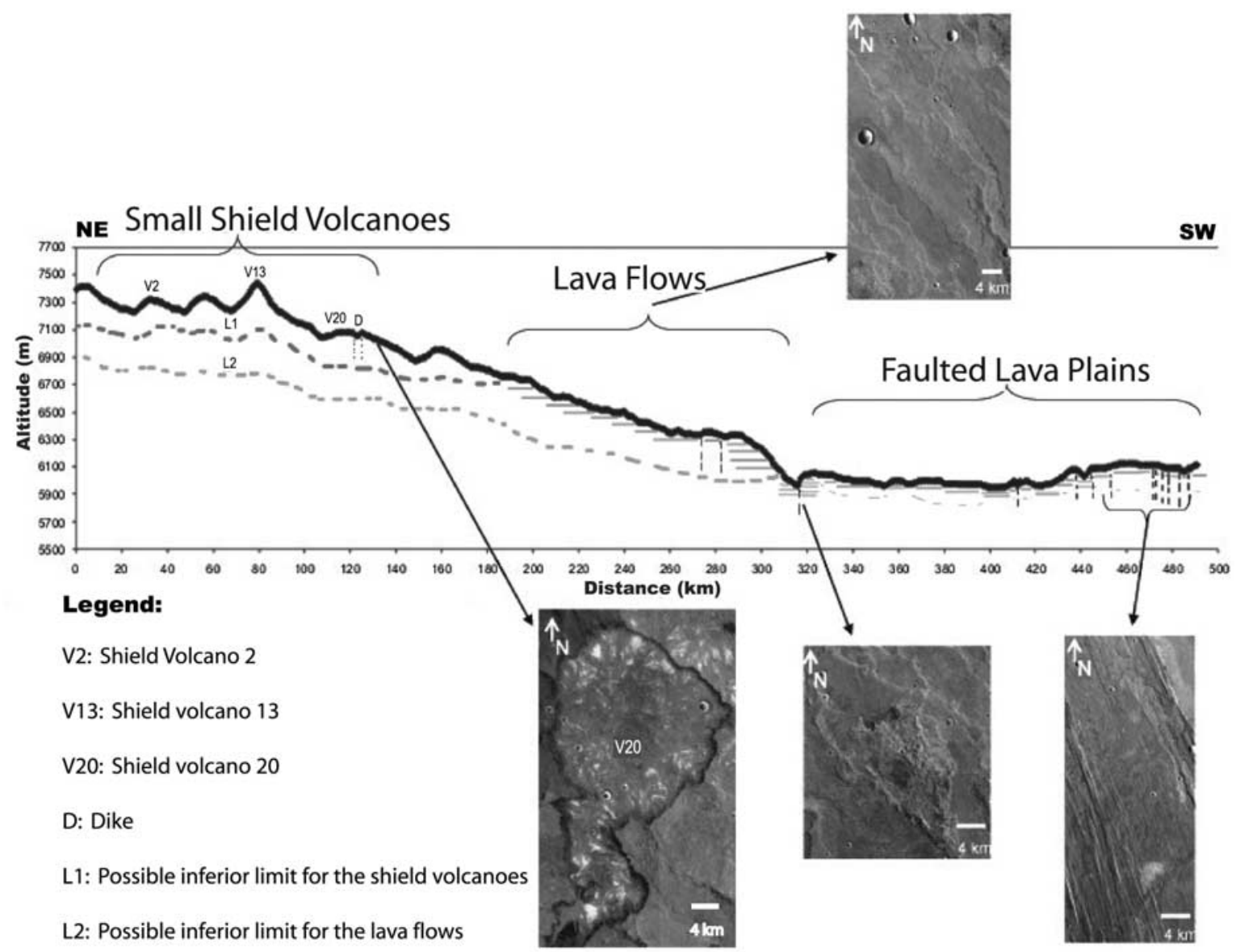

Figure 17. Profile NE-SW from the Syria Planum region. From highest to lowest altitudes we can observe the succession of the low shield volcanoes, the lava flows intersected by predominantly NE-SW fissures, and the highly faulted lava terrains.

means that the main volcanic activity in Syria Planum occurred during this period.

\section{Synthesis: Chronology of Volcanic and Tectonic Episodes}

[47] Our study of the HRSC images suggests that a much more complex geologic history of Syria Planum exists than was previously expected, especially in light of the identification of a unique swarm of small shield volcanoes that occur in the most elevated part of the region (Figure 17). Southwest of these edifices, $\sim 200 \mathrm{~km}$ long lava flows erupted from a volcano also not previously identified. Both volcanic systems have embayed the highly faulted crust that is only visible in the southern part of the region (example on Figure 17).

[48] The geological episodes that existed in this location can be chronologically described in the following phases:

[49] 1. Formation of the grabens, with a few on the order of $4 \mathrm{~km}$ width, which is dated to the late Noachian to early Hesperian epoch [Tanaka and Davis, 1988].

[50] 2. Formation of volcano $\mathrm{A}$ in the early Hesperian, which partially covers the grabens of phase 1 (Figures 12$15)$, but are not cut by these grabens.
[51] 3. Lava flows from volcano A are cut by NE-SW faulting events of early Hesperian age. In some areas, the faults may serve as conduits for magma eruptions that postdate the lava flows from volcano A. In that case, phases 3 and 4 are almost contemporaneous (Figure 15).

[52] 4. A swarm of shield volcanoes (formed during the Hesperian period) are superimposed on these lava flows (Figure 17). Also, at least three volcanic shields are clearly superimposed on lava flows from volcano A (see volcano 5 on Figure 12a or volcanoes 11 and 12 on Figure 15).

[53] 5. A few depressions formed by collapse might signify the last episode of activity, perhaps generated by the Noctis Labyrinthus opening in, or after, the late Hesperian (Figure 12).

[54] The schematic cross section in Figure 17 also shows that the total unit of Hesperian-aged volcanic landforms does not have a large thickness. From the relationship with the fault system to the south, it is likely that the total thickness of this material does not exceed $2 \mathrm{~km}$, although it is difficult to estimate a boundary that depends on preexisting terrains (now completely buried). This remark is important because it shows that the elevation acquired by Syria Planum predates the age of the visible surface, at least to the elevation of about $6 \mathrm{~km}$ over Mars datum, suggesting the 
Noachian rise of the bulge reached this minimum value of $6 \mathrm{~km}$.

\section{Discussion}

[55] The suite of volcanotectonic episodes identified in Syria Planum has two specific characteristics that require a few comments. First, swarms of coalesced small shield volcanoes are not usual in the Tharsis region. What kind of volcanic phase do they indicate? How are they related to volcano A? Second, our work shows that the volcanism in this area ended during the Hesperian epoch. Why did it end whereas the northern and western parts of the Tharsis region continued to display volcanic activity throughout the next $3 \mathrm{Ga}$ ?

[56] To answer the first question, we first note that both earlier studies of Martian volcanism [e.g., Greeley and Crown, 1990; Crown and Greeley, 1993] and more recent works [e.g., Plescia, 2004] proposed that the older volcanoes have smaller volumes and dimensions than the younger giant shields. Syria Planum small shield volcanoes are of a relative age older than the Tharsis shield volcanoes (at least to their current surfaces). Nevertheless, volcano A has many characteristics similar to the Tharsis Montes, such as the effusion rates, except that it did not grow as high as the Tharsis Montes. In addition, isolated small shield volcanoes were already observed in the flanks of Pavonis Mons and in the caldera of Arsia Mons as well as an extensive field of small vents on Ascraeus Mons [e.g., Greeley and Spudis, 1981; Hodges and Moore, 1994; Bleacher et al., 2007]. Greeley [1977, 1982] characterizes it as a plains-style volcanic field area, where lava flows between the low shields and fissures were emplaced via a combination of lava tubes and extensive sheets. As they are distal to the caldera, or to the last volcanic episodes on the flanks, they might be a sign of late activity in the region of the large Tharsis Montes [Bleacher et al., 2007], probably from the late Amazonian, an age much younger than the Syria Planum volcanoes. Syria Planum was dominated both by swarms of coalesced small shields and a single larger edifice (volcano A) as the source of long lava flows. The small shield volcanoes might signify late-stage activity that once began with the emplacement of volcano A, identified by long lava flows and a lava viscosity similar to the Tharsis Montes. This volcano A might never have reached the stage to enable the construction of a larger volcano at this location.

[57] This style of multistaged volcanic activity suggests that there is a need to examine the role of the local lithospheric structure. It is of note that the heights of volcanoes may provide significant constraints on the lithospheric thickness for terrestrial planets [e.g., Blasius and Cutts, 1976]. Assuming that the heights of the shield volcanoes are hydrostatically limited, there is a simple relationship between the height of the volcano and the base of the lithosphere considered to be the source of the magma. The region of Syria Planum is characterized by a thick crust of more than $80 \mathrm{~km}$ (from Neumann et al. [2004]) and the highest altitude of the Tharsis region [Neumann et al., 2004]. Furthermore, according to Neumann et al. [2004], the deepest mantle, or the deepest Mars-equivalent Moho interface, occurs in southern Tharsis, near Syria and Solis Planum. Considering that the crust has a lower thermal conductivity $\left(\sim 2.5 \mathrm{~W} \mathrm{~K}^{-1} \mathrm{~m}^{-1}\right)$ than the mantle $\left(\sim 4 \mathrm{~W} \mathrm{~K}^{-1} \mathrm{~m}^{-1}\right)$ [Schumacher and Breuer, 2006], this fact implies that the present lithosphere is thinner below this region. The elastic thickness of the lithosphere $\left(T_{e}\right)$ at the time of loading has been estimated independently from gravity/topography admittances [McGovern et al., 2002]. Below Solis Planum, a region having a thick crust in the immediate vicinity of Syria Planum, $T_{e}$ ranges from about $40-60 \mathrm{~km}$ corresponding to $10-15 \mathrm{~K} \mathrm{~km}^{-1}$, whereas $T_{e}$ has been estimated at twice this value below the Tharsis Montes. It is thus possible that the structure below Syria Planum is characterized by a thick crust associated with a thin lithosphere at the time of the magmatic activity, which has resulted in shallower magma sources in Syria Planum. As a consequence, the maximum height for the possible volcanic constructs in this region was more limited than in the other regions of the Tharsis plateau. We therefore suggest that the cessation of activity of a large volcano on Syria Planum might signify the presence of a thicker crust in that part of the bulge. This would explain the incomplete development of the larger volcano at this location by the end of the volcanism, early in the geologic history of the Tharsis region.

[58] In summary, we hypothesize that Syria Planum shield volcanoes played an important role in the primordial Tharsis volcanism and that their activity ceased early in the geologic history of this region. The progressive cessation of activity might be due to the enhanced crustal thickness in the magmatic processes of this region. The highest crustal thickness beneath Syria Planum led us to focus on its principal role in the origin, but also the decline, of volcanism in this area and its continuation on the northwestern side of Tharsis, leading to the formation of the present Tharsis Montes. However, in addition to the geological evidence, detailed geophysical studies are still needed to support this hypothesis.

[59] In previous works [e.g., Anderson et al., 2004; Scott and Wilson, 2003] it was suggested that the thickened crust under Syria Planum is a result of the formation of the Syria plain volcanism itself. In our study, the thick crust is clearly not due to the accumulation of Hesperian lava flows, which we can limit to 1-2 km (see on Figure 17). Indeed, Noachian age terrain with faulted outcrops are observed at elevations of $5700-5900 \mathrm{~m}$. Assuming that this terrain was flat below Syria, this implies a thickness of $1.5 \mathrm{~km}$ for the Hesperian lava flows. A possibility is that these terrains could be tilted by the bulge beneath the Syria Planum unit (as shown by dotted lines on Figure 17); in that case, the thickness of Hesperian lavas can be lower $(<1 \mathrm{~km})$. Nevertheless, the lack of Noachian crater rim outcrops in Syria Planum suggests the first hypothesis $(1-2 \mathrm{~km})$ is more likely. This also implies that Syria Planum was already an area at a high elevation at the end of the Noachian, in agreement with our proposed timing for the Tharsis bulge formation.

\section{Conclusions}

[60] HRSC images combined with MOLA and THEMIS data enable a better understanding of some geophysical processes and structures in the Syria Planum region of Mars. The Syria Planum region reveals the following 
original pattern of volcanic features distinct from the other areas over the Tharsis bulge:

[61] 1. Syria Planum contains a swarm of small shield volcanoes centered in the northeast. Each volcano has a small height $(<0.3 \mathrm{~km})$ and relatively moderate diameter $(10-60 \mathrm{~km})$, with a small slope $\left(<2^{\circ}\right)$ compared to most other Martian volcanoes. They may have formed because of fissure-fed eruptions.

[62] 2. A larger volcano (volcano A) is identified west of the small shield swarm. It displays long lava flows $(>200 \mathrm{~km})$ resulting from high effusion rates. On the basis of our investigation, we conclude that these lavas flows are likely to be basaltic to andesitic in composition, similar to Montes lava flows.

[63] 3. The small shield volcanoes and the extensive lava flows of volcano A appear to be structurally different and chronologically distinct, despite that no precise timescale can be proposed. In comparison with the elongated lava flows, the small shield volcanoes imply a lower volcanic eruption volume that was subsequent to the flows from volcano A. We propose that this progressive cessation of activity might be due to the role of the enhanced crustal thickness in the magmatic processes of this region.

[64] 4. We can constrain the formation of Syria Planum to the following successive magmatic and tectonic events from the early to the late Hesperian period: (1) extensional field stress that produced grabens; (2) eruption of volcano A resulting in lavas that spread all over Syria Planum; (3) tectonic deformation of the emplaced lava flows by the formation of several fractured patterns such as NE-SW en echelon faults, troughs, and adjacent grabens; and (4) new episodes of volcanic activity, forming the coalesced small shield swarms that bury preexisting faults.

[65] Acknowledgments. We wish to thank J. Plescia, J.M. Byrnes, L. Keszthelyi, and an anonymous reviewer for careful and constructive reviews, H. Massol for her comments, and R. Bulow for the English corrections. We acknowledge the HRSC experiment teams for their successful planning, acquisition, and making the processed data available to the HRSC team. This work is supported by a FCT (Foundation for the Science and Technology, on the QCA III European Community Support Program for 2000-2010 in Portugal) grant to A.R.B. and grants from the Programme National de Planétologie (PNP) of Institut National des Sciences de l'Univers (INSU) and Centre National d'Etudes Spatiales (CNES) for French authors.

\section{References}

Anderson, R. C., J. M. Dohm, M. P. Golombeck, A. F. C. Haldemann, B. J. Franklin, K. L. Tanaka, J. Lias, and B. Peer (2001), Primary centers and secondary concentrations of tectonic activity through time in the western hemisphere of Mars, J. Geophys. Res., 106, 20,563-20,586, doi:10.1029/ 2000JE001278.

Anderson, R. C., J. M. Dohm, A. F. C. Haldemann, T. M. Hare, and V. R. Baker (2004), Tectonic histories between Alba Patera and Syria Planum, Mars, Icarus, 171, 31-38.

Blasius, K. R., and J. A. Cutts (1976), Shield volcanism and lithospheric structure beneath the Tharsis plateau, Mars, Proc. Lunar Sci. Conf., 7th, $3561-3573$.

Bleacher, J. E., R. Greeley, D. A. Williams, and G. Neukum (2007), Morphometric characterization and comparison among the Tharsis Montesrelated low shield and fissure vent fields, Lunar Planet. Sci., XXXVIII, Abstract 1314

Carr, M. H. (1973), Volcanism on Mars, J. Geophys. Res., 78, 4049-4062, doi:10.1029/JB078i020p04049.

Carr, M. H. (1974), Tectonism and volcanism of the Tharsis region of Mars, J. Geophys. Res., 79, 3943-3949, doi:10.1029/JB079i026p03943.

Carr, M. H. (1975), The volcanoes of Mars, Sci. Am., 234, 32-43.

Carr, M. H. (1981), The Surface of Mars, chap. 7, 87-113, Yale Univ.

Press, New Haven, Conn.
Carr, M. H. (1996), Water on Mars, Oxford Univ. Press, New York.

Cattermole, P. (1987), Sequence, rheological properties, and effusion rates of volcanic flows at Alba Patera, Mars, Proc. Lunar Planet. Sci. Conf., 17th, Part 2, J. Geophys. Res., 92, Suppl. E553-E560.

Cattermole, P. (1990), Volcanic flow development at Alba Patera, Mars, Icarus, 83, 453-493, doi:10.1016/0019-1035(90)90079-O.

Chadwick, D. J., S. S. Hughes, and S. E. H. Sakimoto (2004), Deflections in lava flow directions relative to topography in the Tharsis region of Mars: Indications of post-flow tectonic motion, paper presented at Second Conf. on Early Mars, Lunar and Planet. Inst., Jackson Hole, Wyo., $11-$ 15 Oct.

Christensen, P. R. (2003), Evidence for recent climate fluctuations on Mars: From cold to colder, Eos Trans. $A G U, 84(46)$, Fall Meet. Suppl., Abstract P32B-01.

Crown, D. A., and R. Greeley (1993), Volcanic geology of Hadriaca Patera and the eastern Hellas region of Mars, J. Geophys. Res., 98, 3431-3451, doi:10.1029/92JE02804.

Davis, P. A., and K. L. Tanaka (1993), Small volcanoes in Tempe Terra, Mars: Their detailed morphometry and inferred geologic significance, Proc. Lunar Planet. Sci. Conf., 24th, 379-380.

Dohm, J. M., K. L. Tanaka, and T. M. Hare (2001), Geologic map of the Thaumasia region of Mars, U. S. Geol. Surv. Misc. Invest. Map, I-2650, scale: $1: 5,000,000$.

Fink, J. H., and J. R. Zimbelman (1986), Rheology of the 1983 Royal Gardens basalt flows, Kilauea volcano, Hawaii, Bull. Volcanol., 48, 87-96, doi:10.1007/BF01046544.

Frey, H. (1979), Thaumasia: A fossilized early forming Tharsis uplift, J. Geophys. Res., 84, 1009-1023.

Greeley, R. (1973), Mariner 9 photographs of small volcanic structures on Mars, Geology, 1, 175-180, doi:10.1130/0091-7613(1973)1<175: MPOSVS $>2.0$.CO;2.

Greeley, R. (1977), Basaltic "plains" volcanism, in Volcanism of the Eastern Snake River Plain, Idaho: A Comparative Planetary Geology Guidebook, edited by R. Greeley and J. S. King, NASA Conf. Rep. 154621, $23-44$.

Greeley, R. (1982), The Snake River Plain, Idaho: Representative of a new category of volcanism, J. Geophys. Res., 87, 2705-2712, doi:10.1029/ JB087iB04p02705.

Greeley, R., and D. Crown (1990), Volcanic geology of Tyrrhena Patera, Mars, J. Geophys. Res., 95, 7133-7149. (Correction, J. Geophys. Res., 95, 15,657, 1990.)

Greeley, R., and P. D. Spudis (1981), Volcanism on Mars, Rev. Geophys., 19, 13-41, doi:10.1029/RG019i001p00013.

Gregg, T. K. P., and J. H. Fink (1996), Quantification of extraterrestrial lava flow effusion rates through laboratory simulations, J. Geophys. Res., 101, 16,891-16,900, doi:10.1029/96JE01254.

Hartmann, W. K., and G. Neukum (2001), Cratering chronology and the evolution of Mars, Space Sci. Rev., 96(1-4), 165-194.

Hartmann, W. K., J. A. Grier, D. C. Berman, and G. A. Esquerdo (2000), The case for youthful geological activity on Mars, Bull. Am. Astron. Soc., $32,1111$.

Hauber, E., and P. Kronberg (2001), Tempe Fossae, Mars: A planetary analogon to a terrestrial continental rift?, J. Geophys. Res., 106, 20587, doi:10.1029/2000JE001346.

Hauber, E., J. Bleacher, D. Williams, and R. Greeley (2007), Plains volcanism on Mars revisited: The topography and morphology of low shields and associated volcanic landforms, paper presented at European Mars Science and Exploration Conference: Mars Express \& ExoMars, Eur. Space Agency, Noordwijk, Netherlands.

Head, J. W., III, M. A. Ivanov, H. Hiesinger, M. Kreslavsky, B. Thomson, and S. Pratt (2000), Oceans in the past history of Mars?: Evidence for recession and timing from MOLA data, Lunar Planet. Sci., XXXI, Abstract 1750 .

Hiesinger, H., et al. (2005), Rheological properties of late-stage lava flows on Ascraeus Mons: New evidence from HRSC, Lunar Planet. Sci., $X X X V I$, Abstract 1727.

Hiesinger, H., J. W. Head, and G. Neukum (2007), Young lava flows on the eastern flank of Ascraeus Mons: Rheological properties derived from High Resolution Stereo Camera (HRSC) images and Mars Orbiter Laser Altimeter (MOLA) data, J. Geophys. Res., 112, E05011, doi:10.1029/ 2006JE002717.

Hodges, C. A., and H. J. Moore (1994), Atlas of Volcanic Landforms on Mars, U.S. Gov. Print. Off., Washington D. C.

Hulme, G. (1976), The determination of the rheological properties and effusion rate of an Olympus Mons lava, Icarus, 27, 207-213, doi:10.1016/0019-1035(76)90004-X.

Hulme, G., and G. Fielder (1977), Effusion rates and rheology of lunar lavas, Philos. Trans.R. Soc. London, Ser. A, 285, 227-234, doi:10.1098 rsta. 1977.0059 
Knudson, J. G., and D. L. Katz (1979), Fluid Dynamics and Heat Transfer, 576 pp., R.E. Krieger, Huntington, N.Y.

Malin, M. C. (1977), Comparison of volcanic features of Elysium (Mars) and Tibesti (Earth), Geol. Soc. Am. Bull., 88, 908-919, doi:10.1130/ 0016-7606(1977) $88<908$ : $\mathrm{COVFOE}>2.0 . \mathrm{CO} ; 2$.

Masson, P. (1980), Contribution to the structural interpretation of the Valles Marineris-Noctis Labyrinthus-Claritas Fossae regions of Mars, Moon Planets, 22, 211-219.

McGovern, P. J., S. C. Solomon, D. E. Smith, M. T. Zuber, M. Simons, M. A. Wieczorek, R. J. Phillips, G. A. Neumann, O. Aharonson, and J. W. Head (2002), Localized gravity/topography admittance and correlation spectra on Mars: Implications for regional and global evolution, J. Geophys. Res., 107(E12), 5136, doi:10.1029/2002JE001854.

Meresse, S., et al. (2008), Formation and evolution of the chaotic terrains by subsidence and magmatism: Hydraotes Chaos, Mars, Icarus, 194 , $487-500$

Moore, H. J., D. W. G. Arthur, and G. G. Schaber (1978), Yield strengths of flows on the Earth, Moon, and Mars, Proc. Lunar Planet. Sci. Conf., 9th, $750-751$

Mouginis-Mark, P. J., L. Wilson, and M. Zuber (1992), The physical volcanology of Mars, in Mars, pp. 424-452, Univ. of Ariz. Press, Tucson.

Mutch, T. A., R. E. Arvidson, J. W. Head III, K. L. Jones, and R. S Saunders (1976), The Geology of Mars, chap. 4, pp. 151-201, Princeton Univ. Press, Princeton, N.J.

Neumann, G. A., M. T. Zuber, M. A. Wieczorek, P. J. McGovern, F. G. Lemoine, and D. E. Smith (2004), Crustal structure of Mars from gravity and topography, J. Geophys. Res., 109, E08002, doi:10.1029/ 2004JE002262.

Pinkerton, H., and L. Wilson (1994), Factors controlling the lengths of channel-fed lava flows, Bull. Volcanol., 56, 108-120.

Plescia, J. B. (1981), The Tempe volcanic province of Mars and comparisons with the Snake River Plains of Idaho, Icarus, 45, 586-601, doi:10.1016/0019-1035(81)90024-5.

Plescia, J. B. (2004), Morphometric properties of Martian volcanoes, J. Geophys. Res., 109, E03003, doi:10.1029/2002JE002031.

Plescia, J. B., and S. Saunders (1982), Tectonic history of the Tharsis region, Mars, J. Geophys. Res., 87, 9775-9791, doi:10.1029/ JB087iB12p09775.

Rossi, M. J. (1996), Morphology and mechanism of eruption of postglacial shield volcanoes in Iceland, Bull. Volcanol., 57, 530-540.

Sakimoto, S. E. H. (2003), Re-assessing plains-style volcanism on Mars, paper presented at 6th International Conference on Mars, Lunar and Planet. Inst., Pasadena, Calif., Abstract 3197.

Sakimoto, S. E. H., J. Crisp, and S. M. Baloga (1997), Eruption constraints on tube-fed planetary lava flows, J. Geophys. Res., 102, 6597-6614, doi:10.1029/97JE00069.

Sakimoto, S. E. H., T. K. P. Gregg, S. S. Hughes, and J. Chadwick (2003), Martian plains volcanism in Syria Planum and Tempe Mareotis as analogs to the eastern Snake River Plains, Idaho: Similarities and possible petrologic contributions to topography, Lunar Planet. Sci., XXXIV, Abstract 1740.

Schumacher, S., and D. Breuer (2006), Influence of a variable thermal conductivity on the thermochemical evolution of Mars, J. Geophys. Res., 111, E02006, doi:10.1029/2005JE002429.

Scott, D. H., and K. L. Tanaka (1998), Geological map of the equatorial region of Mars, U.S. Geol. Surv. Misc. Invest. Map I-1802-A, scale: $1: 15,000,000$.
Scott, E., and L. Wilson (2003), Did the Alba Patera and Syria Planum regions of Mars lose their lithospheric roots in convective overturn events?, J. Geophys. Res., 108(E5), 5035, doi:10.1029/2002JE001492.

Smith, D. E., et al. (2001), Mars Orbiter Laser Altimeter (MOLA): Experiment summary after the first year of global mapping of Mars, $J$. Geophys. Res., 106, 23,689-23,722, doi:10.1029/2000JE001364.

Tanaka, K. L., and P. A. Davis (1988), Tectonic history of the Syria Planum province of Mars, J. Geophys. Res., 93, 14,893-14,917, doi:10.1029/ JB093iB12p14893.

Tanaka, K. L., and J. M. Dohm (1989), Volcanotectonic provinces of the Tharsis region of Mars: Identification variations, and implications, paper presented at MEVTV Workshop on Early Tectonic and Volcanic Evolution of Mars, Lunar and Planet. Inst., 79-81.

Vaucher, J., et al. (2006), Cerberus Plains, Mars: Chronology of volcanic event and evidence of recent tectonic activity, Lunar Planet. Sci., XXXVII, Abstract 1851.

Warner, N. H., and T. K. P. Gregg (2003), Evolved lavas on Mars? Observations from southwest Arsia Mons and Sabancaya volcano, Peru, J. Geophys. Res., 108(E10), 5112, doi:10.1029/2002JE001969.

Webb, B., J. W. Head III, B. E. Kortz, and S. Pratt (2001), Syria Planum, Mars: A major volcanic construct in the early history of Tharsis, Lunar Planet. Sci., XXXII, Abstract 1145

Wilson, L. (2001), Evidence for episodicity in the magma supply to the large Tharsis volcanoes, J. Geophys. Res., 106, 1423-1434, doi:10.1029/ 2000JE001280.

Wilson, L., and J. W. Head (1981), Volcanic eruption mechanisms on Mars: Some theoretical constraints, Lunar Planet. Sci., XII, 1194-1196.

Wilson, L., and J. W. Head (1983), A comparison of volcanic eruption processes on Earth, Moon, Mars, Io and Venus, Nature, 302, 663-669, doi:10.1038/302663a0

Wilson, L., and J.W. Head III (1994), Mars: Review and analysis of volcanic eruption theory and relationships to observed landforms, Rev. Geophys., 32, 221-263.

Zimbelman, J. R. (1985), Estimates of rheologic properties for flows on the Martian volcano Ascraeus Mons, Proc. Lunar Planet. Sci. Conf. 16th, Part 1, J. Geophys. Res., 90, suppl. D157-D162.

Zuber, M. T., D. E. Smith, R. J. Phillips, S. C. Solomon, W. B. Banerdt, G. A. Neumann, and O. Aharonson (1998), Shape of the northern hemisphere of Mars from the Mars Orbiter Laser Altimeter (MOLA), Geophys. Res. Lett., 25, 4393-4396, doi:10.1029/1998GL900129.

E. I. Alves, Centro de Geofísica da Universidade de Coimbra, Avenida Doutor Dias da Silva, P-3000-134 Coimbra, Portugal

V. Ansan, N. Mangold, and P. Masson, IDES, Université Paris XI, Batiment 509, F-91405 Orsay CEDEX, France.

A. R. Baptista and P. Lognonné, Géophysique Spatiale et Planétaire, Institut de Physique du Globe de Paris, 4 Avenue de Neptune, F-94107 Saint Maur des Fossés, France. (baptista@ipgp.jussieu.fr)

D. Baratoux, Laboratoire Dynamique Terrestre et Planétaire, UMR5562, Observatoire Midi-Pyrénées, Université de Toulouse III, 14 Avenue Edouard Belin, F-31400 Toulouse, France.

J. E. Bleacher, Planetary Geodynamics Laboratory, NASA Goddard Space Flight Center, Code 698, Greenbelt, MD 20771, USA.

G. Neukum, Institut für Geologische Wissenschaften, Freie Universität Berlin, Malteserstrasse 74-100, D-12249 Berlin, Germany.

D. A. Williams, School of Earth and Space Exploration, Arizona State University, P.O. Box 871404, Tempe, AZ 85287, USA. 